\title{
Vertical and temporal variability in concentration and distribution of thaumarchaeotal tetraether lipids in Lake Superior and the implications for the application of the $\mathrm{TEX}_{86}$ temperature proxy
}

\author{
Martijn Woltering ${ }^{a, *}$, Josef P. Werne ${ }^{\mathrm{a}, \mathrm{b}, 1}$, Jason L. Kish ${ }^{\mathrm{c}}$, Randall Hicks ${ }^{\mathrm{c}}$, \\ Jaap S. Sinninghe Damsté ${ }^{\text {d,e }}$, Stefan Schouten ${ }^{\text {d,e }}$ \\ ${ }^{a}$ Large Lakes Observatory, University of Minnesota Duluth, 10 University Dr., Duluth, MN 55812, USA \\ ${ }^{\mathrm{b}}$ Department of Chemistry \& Biochemistry, University of Minnesota Duluth, 10 University Dr., Duluth, MN 55812, USA \\ ${ }^{\mathrm{c}}$ Department of Biology, University of Minnesota Duluth, 10 University Dr., Duluth, MN 55812, USA \\ ${ }^{\mathrm{d}}$ NIOZ Royal Netherlands Institute for Sea Research, Department of Marine Organic Biogeochemistry, P.O. Box 59, \\ 1790 AB Den Burg, Texel, The Netherlands \\ ${ }^{\mathrm{e}}$ Department of Geosciences, Utrecht University, Budapestlaan 4, 3584 CD Utrecht, The Netherlands
}

Received 6 October 2010; accepted in revised form 13 December 2011; available online 24 March 2012

\begin{abstract}
This study investigated the vertical and temporal distribution of Thaumarchaeota derived core isoprenoid glycerol dialkyl glycerol tetraether (GDGT) lipids through sampling and analysis of both suspended particulate matter from the water column at different times in the annual cycle and a 3 year long record of settling particles in two sediment traps at different depths at an open lake location in Lake Superior. Results from these analyses suggest that Thaumarchaeota were present throughout the water column during times of overturning, but mainly resided below the depth of the thermocline (20-40 m) during the period of thermal stratification. Fluxes of thaumarchaeotal produced GDGTs were highly periodic and mainly occurred during two periods of the annual cycle (winter and late spring/early summer). A covariance of both branched and isoprenoid GDGT fluxes with the mass accumulation flux combined with the observation that those periods of maximum fluxes were associated with increased BIT index values, however, suggest that these two periods of elevated fluxes may be related to an influx of resuspended particles transported from shallower near shore regions of Lake Superior. During all sampling periods TEX 86 inferred temperatures from SPM were in good agreement with in situ water temperatures of the depths at which the SPM was sampled. The observed range of $\mathrm{TEX}_{86}$ inferred temperatures in 3 years of settling particles is relatively small and does not show significantly higher inferred temperatures during the thermally stratified period, indicating that the sedimentary $\mathrm{TEX}_{86}$ signal during the summer thermally stratified period mainly originated from depths below the relatively shallow thermocline. Additionally, $\mathrm{TEX}_{86}$ values during the winter period of increased fluxes did not capture the decrease in water temperatures observed throughout the water column during this period, and thus may be a further indication that the thaumarchaeotal lipid flux was the result of sediment focusing. Flux-weighted TEX ${ }_{86}$ inferred temperatures from both sediment traps were in good agreement with $\mathrm{TEX}_{86}$ temperatures from surface sediments from the same location in Lake Superior. Both flux weighted $\mathrm{TEX}_{86}$ temperatures from the sediment traps and average $\mathrm{TEX}_{86}$ temperatures from surface sediments were similar to averaged measured water temperatures at below $\sim 40 \mathrm{~m}$ depth within the error of the lacustrine \footnotetext{
Western Australia, Australia.

E-mail address: wolte082@umn.edu (M. Woltering).

${ }^{1}$ Work prepared while on leave at the Centre for Water Research, University of Western Australia, Crawley, Western Australia, Australia and WA-Organic and Isotope Geochemistry Centre, Curtin University of Technology, Bentley, Western Australia, Australia.
}

* Corresponding author. Current address: WA-Organic and Isotope Geochemistry Centre, Curtin University of Technology, Bentley,
\end{abstract}


TEX $_{86}$ calibration. Based on the observed depths of Thaumarchaeota in the water column, TEX $_{86}$ values in sediments of Lake Superior likely reflect a combination of mixed-season and sub-thermocline temperatures. This is effectively the same as the annual averaged water temperature observed at depths below $40 \mathrm{~m}$ in Lake Superior. Thus, trends in TEX 86 inferred temperatures in sediment records of Lake Superior, and similar lakes, are likely to reflect subsurface temperature variability rather than that of surface temperatures.

(c) 2012 Elsevier Ltd. All rights reserved.

\section{INTRODUCTION}

Lake sediments provide important archives for climate records that span the continental interior. Sediment archives of lakes can produce continuous high-resolution records of past climate change (Meyers, 1997; Cohen, 2003). Lakes are located throughout the continents, span a wide range of latitudes, and show an integrated response to climate variability within their drainage basins. Lake records not only provide information on how climate has changed in the past, but also yield valuable insights of how past life in the lake and its drainage basin responded to climate change. Thus, lake archives are relevant to assess potential societal impacts of future climatic changes on a regional scale.

Recently, the application of the $\mathrm{TEX}_{86}$ proxy has emerged as a new tool to reconstruct past lake surface water temperature, and associated continental air temperatures, from lake sediments (Powers et al., 2004; Tierney et al., 2008). This proxy was originally developed and applied in marine settings and is based upon the relative degree of cyclization in core isoprenoid glycerol dialkyl glycerol tetraether (GDGT) membrane lipids that can contain 0-4 cylopentane moieties (GDGT-0-GDGT-3) or including an unusual GDGT, crenarchaeol that contains a cyclohexane moiety in addition to four cyclopentane moieties (Schouten et al., 2002). These are mainly produced by archaea belonging to the Marine Group 1 Crenarchaeota (Sinninghe Damsté et al., 2002), which recently have been reclassified to Thaumarchaeota, a separate phylum in the domain of archaea (Brochier-Armanet et al., 2008; Spang et al., 2010). Mesocosm studies of sea water have shown that Thaumarchaeota increase the relative amount of GDGTs containing cyclopentane moieties in response to temperature (Wuchter et al., 2004), probably to increase the rigidity of its cell membrane as an adaptation to higher water temperatures as was previously observed in (hyper)thermophilic Crenarchaeota (Gliozzi et al., 1983). Thaumarchaeota similar to those present in the marine environment have been identified in a number of lacustrine systems (MacGregor et al., 1997; Schleper et al., 1997; Pernthaler et al., 1998; Keough et al., 2003) and their core GDGTs, i.e. those without a polar head group formed after cell lysis, were also identified in different lacustrine surface sediments (e.g. Schouten et al., 2000; Powers et al., 2004, 2010; Blaga et al., 2009; Bechtel et al., 2010), confirming the widespread occurrence of Thaumarchaeota in freshwater ecosystems. A strong correlation between $\mathrm{TEX}_{86}$ values from lacustrine surface sediments and annual mean lake surface water temperature (ALST) was observed in some, mainly larger lake systems that is similar to that identified in the marine envi- ronment (Powers et al., 2004, 2010; Blaga et al., 2009). These studies revealed that not all lakes contain the whole suite of lipids used in the $\mathrm{TEX}_{86}$ and that a large contribution of soil organic matter into lakes leads to an input of isoprenoid GDGTs that are not produced in the lakes, therefore potentially interfering with the $\mathrm{TEX}_{86}$ proxy (Weijers et al., 2006a,b). This observation suggested that the use of the $\mathrm{TEX}_{86}$ might be limited to intermediate to large lakes that are only marginally influenced by terrestrial runoff (Blaga et al., 2009; Powers et al., 2010). In such large lakes there is a strong correlation between $\mathrm{TEX}_{86}$ values from surface sediments and both mean winter lake surface temperature (WLST) and annual mean lake surface temperature (ALST) (Blaga et al., 2009; Powers et al., 2010). To date, the $\mathrm{TEX}_{86}$ proxy has been applied in several East African rift lakes to reconstruct long continental temperature records (Powers et al., 2005; Tierney et al., 2008; Woltering et al., 2011).

Despite the obvious importance, relatively little is known about the ecology of Thaumarchaeota in lacustrine ecosystems, and it therefore remains uncertain whether the $\mathrm{TEX}_{86}$-reconstructed temperatures from different lacustrine systems are biased by factors such as seasonality and/ or preferred depth habitat. Lliros et al. (2010) observed that in Lake Kivu, Thaumarchaeota are present throughout the epipelagic waters $(0-100 \mathrm{~m})$ and were associated with both maxima in nitrite and nitrate, suggesting a role of the Thaumarchaeota as aerobic ammonium oxidizers in Lake Kivu. Sinninghe Damsté et al. (2009) observed that in Lake Challa, isoprenoid core GDGTs (excluding GDGT-0) were dominantly produced by Thaumarchaeota in the upper part of the water column and that downward fluxes of isoprenoid GDGTs were highest in January and February, following the principal phytoplankton bloom that occurred just after the local short rainy season. $\mathrm{TEX}_{86}$ inferred temperatures derived from descending particles during this time appear to correspond to lake surface water temperatures of Lake Challa; however, there is evidence of significant in situ production of GDGT-2 in the deeper anoxic waters or the sediment water interface, by an unknown archaeal source, which influences the $\mathrm{TEX}_{86}$ in sediments to such an extent that the proxy in this lake may not be applicable for paleotemperature reconstructions (Sinninghe Damsté et al., 2009). Before the $\mathrm{TEX}_{86}$ temperature proxy can be confidently applied for continental paleotemperature reconstructions, it is important to obtain a better understanding of what, if any, temperature the $\mathrm{TEX}_{86}$ proxy represents in different lakes, including gathering insights about the vertical and temporal distribution of Thaumarchaeota and associated lipid fluxes to the sediments of different lacustrine systems. 
Here, we present results of a study of core GDGTs (i.e. membrane lipids that lost their polar head groups, hereafter referred to as GDGTs) in the water column of Lake Superior, in which the vertical distribution was examined through in situ filtration of suspended particulate matter (SPM), and temporal variability through a three-year time-series sediment trap deployment. SPM filtered from throughout the water column was also studied by quantitative polymerase chain reaction (qPCR) analysis to survey the vertical distribution of $16 \mathrm{~S}$ rRNA genes of all living archaea in Lake Superior, and how it varies seasonally. Isoprenoid GDGT lipids were quantified in SPM to track the fate of the thaumarchaeotal lipids in the water column. $\mathrm{TEX}_{86}$ values of SPM were compared with instrumental water temperatures at the depths sampled and $\mathrm{TEX}_{86}$ values from descending particulate matter collected in sediment traps to determine where in the water column the GDGTs present in settling particles are produced. The major bacterial branched GDGTs were quantified and compared to trends of isoprenoid GDGT concentrations, while the branched isoprenoid tetraether index (BIT index; Hopmans et al., 2004) was used to assess the relative contribution of branched GDGTs relative to the concentration of crenarchaeol. Records of fluxes in the sediment traps provide information on the seasonality of the transport of branched and isoprenoid GDGTs towards the sediments, particularly during the winter when the lake is not accessible by boat (for in situ filtration) due to the presence of ice cover. This study provides insight into the spatial and temporal distribution of thaumarchaeotal production in Lake Superior, thereby placing constraints on the applicability of the $\mathrm{TEX}_{86}$ as a paleotemperature proxy in this and other similar systems.

\section{METHODS}

\subsection{Study site}

Lake Superior, the largest freshwater lake in the world by surface area $\left(82,413 \mathrm{~km}^{2}\right)$, is an ultra oligotrophic lake of glacial origin, located centrally on the North American continent. The ratio of the drainage area of the watershed to the Lake Superior surface area is $\sim 1.55$ (Cotner et al., 2004), an extremely low value for a lake. One implication of this low ratio in Lake Superior is that the lake is influenced far less by the surrounding watershed than most lakes. Because of its size, water in Lake Superior has a residence time of ca. 190 years based on the volume of water in the lake and the mean rate of outflow (Quinn, 1992). Most of the forested, granitic Superior Basin is sparsely populated, with little agriculture because of a cool climate and poor soils (Cotner et al., 2004; Urban et al., 2005).

Our study site is located in the western arm of Lake Superior at $47^{\circ} 19.11^{\prime \prime} \mathrm{N}, 89^{\circ} 52.10^{\prime \prime} \mathrm{W}$ in $180 \mathrm{~m}$ water depth (Fig. 1) in an open lake location more than $50 \mathrm{~km}$ from shore in each direction. This site was selected to avoid complicating factors in the thermal structure of the lake associated with e.g. riverine inputs and upwelling.

Lake Superior is a cold, dimictic lake in a highly seasonal, continental climate. The lake is dominated by a cold hypolimnion (mean annual temperature $\sim 3.5^{\circ} \mathrm{C}$ ) with a thin epilimnion typically forming from July to November that reaches temperatures above $15{ }^{\circ} \mathrm{C}$ (Fig. 2). The starting date and duration of winter thermal stratification in Lake Superior is very sensitive to annual variations in climate; the degree of ice formation in winter is the main control on the date of onset of summer thermal stratification (Austin and Colman, 2007). As a result of Lake Superior's

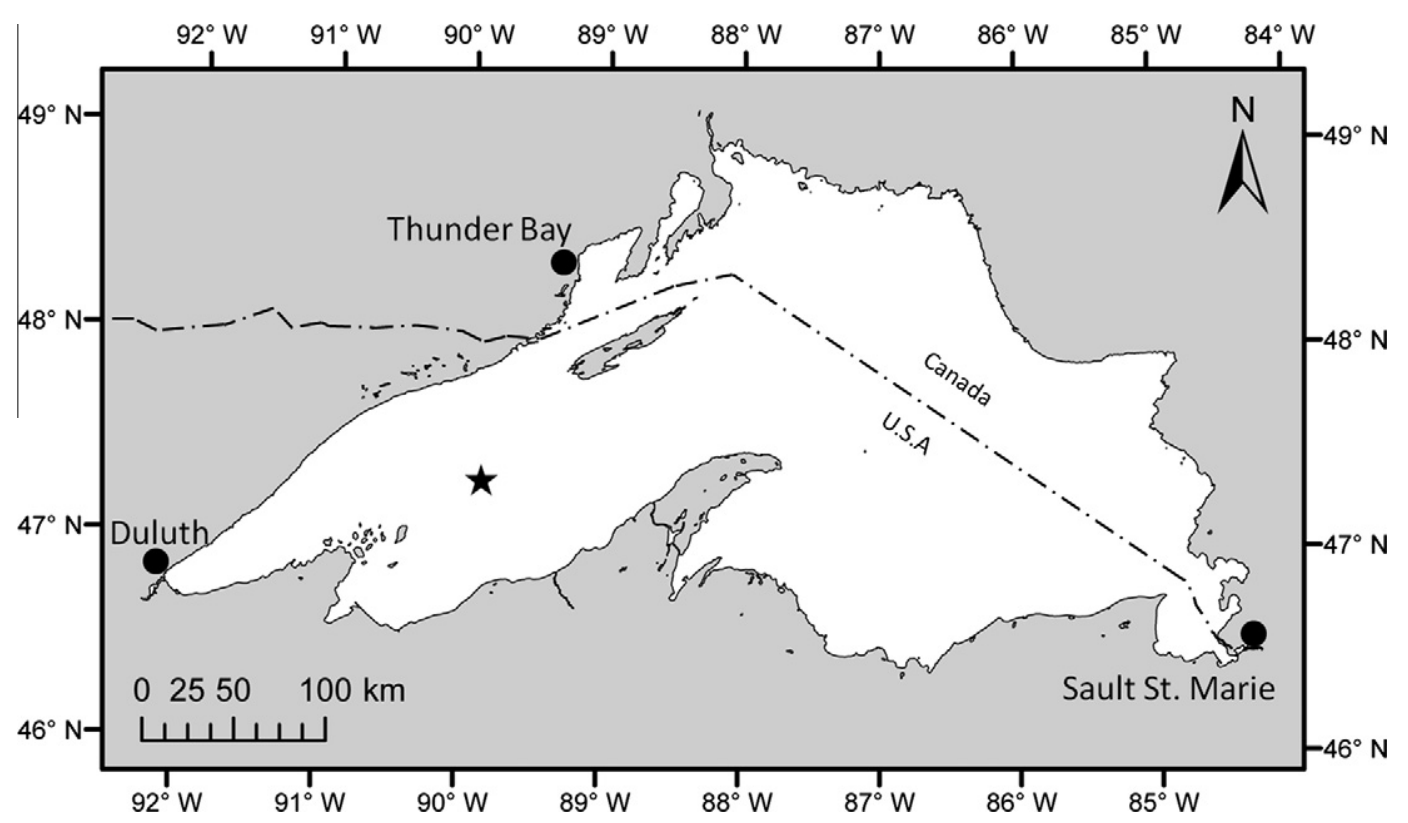

Fig. 1. Map of Lake Superior region showing the sample site (star, $47^{\circ} 19.11^{\prime \prime} \mathrm{N}, 89^{\circ} 52.10^{\prime \prime} \mathrm{W}$ ) in the western arm of Lake Superior. This is an open lake location with $180 \mathrm{~m}$ water depth, distanced away from upwelling areas and riverine inputs. 


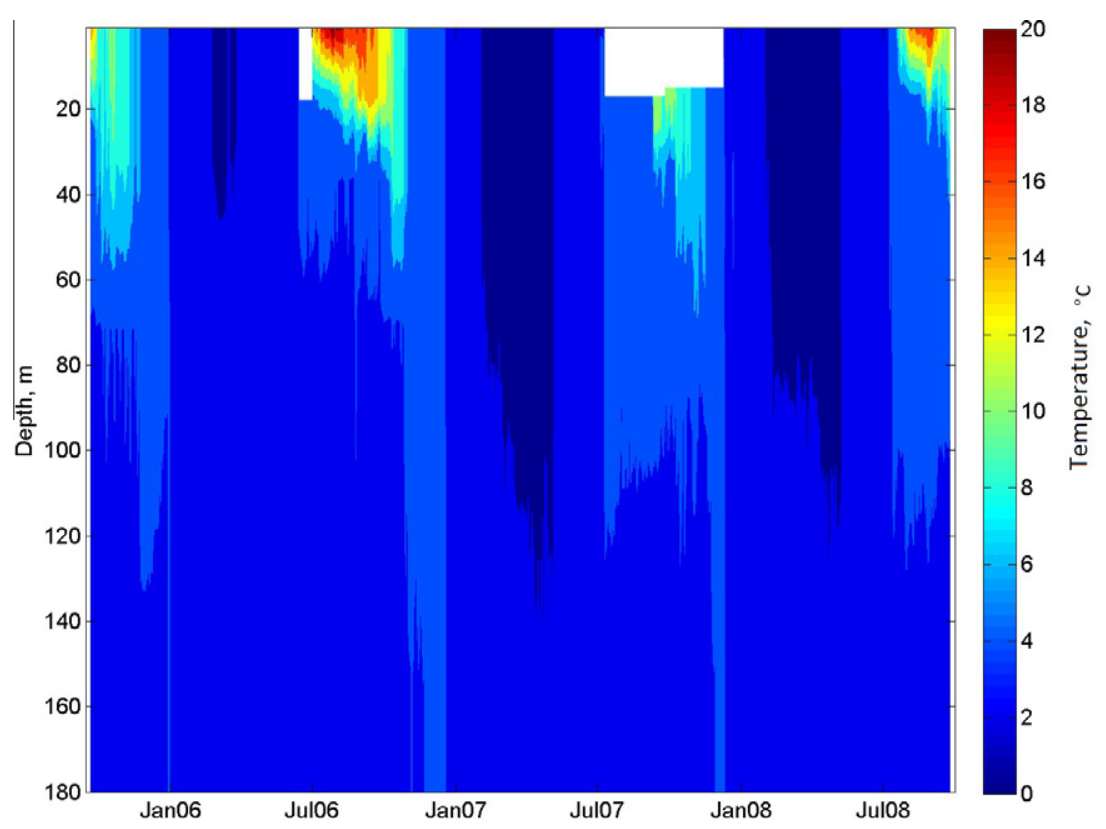

Fig. 2. Contour plot of water temperatures at the study location from September 2005 to 2008. In situ water temperatures were recorded by thermistors on the mooring while surface water temperatures were linearly interpolated using surface temperatures from NOAA buoy Station 45006 located $\sim 1.5$ miles from the sample site. The white boxes during the stratified periods represent times when the NOAA buoy surface water thermistor was defective.

relatively deep waters and high thermal mass of the hypolimnion, warming of the water column at the open lake takes a relatively long time. Thus, "spring" overturn at the study site occurs at the end of spring/beginning of summer (June), pushing the spring diatom bloom to late spring/ early summer followed by the onset of summer stratification around July (Fig. 2). As a result of this temperature behavior of off shore Lake Superior we define summer at the study site as the start of thermal stratification of the water column.

\subsection{Sample collection}

SPM samples were collected at our study site during 4 cruises in May (24-26), July (12-16), August (22-24) and September (26-28) 2007 onboard the R/V Blue Heron, representing the mixed (May and July) and the thermally stratified (August and September) periods. Water column profiles of temperature and chlorophyll-a concentrations were obtained using a SeaBird Model $911^{\circledR}$ plus CTD with fluorometer, transmissometer, PAR sensor, DO sensor, $\mathrm{pH}$ meter and water pressure sensor. Water for Quantitative PCR analyses $(21-40 \mathrm{~L})$ was collected in $8 \mathrm{~L}$ Niskin bottles and filtered onto $142 \mathrm{~mm}(0.22 \mu \mathrm{m}$ pore, Millipore Corp.) Durapore filters. In all cases, water was passed until filters clogged or until $40 \mathrm{~L}$ passed through the filters. All filters were stored at $-80^{\circ} \mathrm{C}$ until DNA was extracted and analyzed. SPM for core GDGT analysis was sampled by a McLane WTS-LV in situ filtration system using $142 \mathrm{~mm}$ diameter pre-combusted $0.7 \mu \mathrm{m}$ nominal pore size Whatman GF/F filters. Typically, $\sim 500 \mathrm{~L}$ of water was filtered at each depth. The filters were stored at $-20^{\circ} \mathrm{C}$ until analysis.

A mooring was deployed in $180 \mathrm{~m}$ of water at the study site for 36 months from September 2005 to September 2008, and serviced each September and May, resulting in "winter" and "summer" deployments. The mooring contained a SeaBird SBE 39 temperature/pressure sensor at $26 \mathrm{~m}$, nine Brancker TR-1050 temperature loggers located at 17, 20, 31, 37, 70, 81, 91, 101 and $120 \mathrm{~m}$, and two McLane Parflux 21 cup sequential sediment traps with a diameter of $0.92 \mathrm{~m}^{2}$ deployed at 65 and $145 \mathrm{~m}$ below the water surface. The sample cups in the sediment traps collected descending particulate matter for 11 days during winter and 6 days during summer deployments. Sediment trap samples were alternately preserved in deionized water from a MilliQ system and $3 \%$ formaldehyde solution in deionized water to assess the potential impact of formaldehyde on RNA and/or lipid preservation. The sediment trap bottles were stored at $-20{ }^{\circ} \mathrm{C}$ until analysis. A fraction of the material collected by the sediment trap was prepared for microscopic analysis by smearing it out to a thin layer onto a microscope slide which was placed into an Olympus ${ }^{\circledR}$ PM-10AD microscope and investigated 100 times magnification. Surface water temperatures were obtained from NOAA Buoy Station 45006 located $\sim 1.5$ mile for the study site, which is generally deployed in the western arm of Lake Superior from April through December. In September 2008 a multi-corer was deployed at the study site to obtain four shallow sediment cores. The top half $\mathrm{cm}$ of sediment was sliced off of three cores to obtain a core top sediment sample.

\subsection{Isoprenoid and branched GDGT analysis}

SPM, sediment trap and core top sediment samples were freeze-dried and homogenized prior to extraction. All freeze dried homogenized samples were ultrasonically extracted with $3 \times$ methanol, $3 \times$ methanol/dichloromethane (DCM) $1: 1 \mathrm{v} / \mathrm{v}$, and $3 \times \mathrm{DCM}$. The supernatant was removed, 
combined and concentrated by rotary evaporation to produce the total extract. The total extract was separated into apolar and polar fractions by column chromatography using an activated $\mathrm{Al}_{2} \mathrm{O}_{3}$ column and eluting with hexane/ DCM 9:1 (apolar fraction, archived for future analysis) and DCM/methanol 1:1 (polar fraction, described below). A known amount of $\mathrm{C}_{46}$ tetraether lipid was added to the polar fraction as internal standard (Huguet et al., 2007a). The polar fraction was dried, dissolved in hexane/2-propanol and filtered over a $0.45 \mu \mathrm{m}$ PTFE filter prior to analysis. Measurement of the core GDGTs was performed on an HP 1100 series LC-MS using an Alltech Prevail Cynano column $(2.1 \times 150 \mathrm{~mm}, 3 \mu \mathrm{m})$ with isocratic elution of hexane and 2-propanol. Core GDGTs were detected using an atmospheric pressure chemical ionization mass spectrometer (ACPI-MS) operating in selected ion monitoring (SIM) following Schouten et al. (2007). The BIT index, which may be used as a proxy for soil derived organic matter relative to aquatically produced organic matter, was calculated from the concentrations of the branched GDGTs and crenarchaeol according to Hopmans et al. (2004) where values of close to 1 would represent predominantly soil derived organic matter and close to 0 pure aquatically derived organic matter.

$\mathrm{TEX}_{86}$ values were calculated according to Schouten et al. (2002) and converted to temperatures using the Powers et al. (2010) lacustrine $\mathrm{TEX}_{86}$ calibration curve of ALST $=-14.0+55.2^{*}\left(\mathrm{TEX}_{86}\right)$ which has a calibration error of $\pm 3.6^{\circ} \mathrm{C}$. In addition, the analytical error was $\pm 0.4^{\circ} \mathrm{C}$ (observed analytical error in duplicate measurements of the Lake Superior SPM was $\sim 0.4{ }^{\circ} \mathrm{C}$ ). The relatively large estimated calibration error of Powers et al. (2010) is likely caused by a combination of factors, primarily the limited number of lakes in the calibration $(N=12)$, inaccurate annual mean surface water temperature data, ecological differences among the different lakes that are yet to be determined, the possibility that some samples in the calibration are older than surface sediments (and so do not correlate with present-day annual mean water temperatures), and in-lake temperature variability rendering samples from a given site not representative of the whole lake average temperature. Powers et al. (2010) calculated the standard error of estimation for their linear regression, which is a relatively conservative estimate of error. An alternative approach of estimating calibration error is by applying a leave-one-out cross validation method (Efron, 1983) and using surface sediment from the study location to calculate the maximum deviation of $\mathrm{TEX}_{86}$ derived temperature from a surface sediment as result of removing individual calibration points from the calibration curve (as described in Supplementary material in Tierney et al., 2010). Utilizing this approach yields a leave one out estimation error of $1.0^{\circ} \mathrm{C}(2 \sigma)$ and combining this error with the analytical standard error determined from duplicate sample measurements $\left(0.4^{\circ} \mathrm{C}\right)$ would yield a total estimated error of about $1.1{ }^{\circ} \mathrm{C}$.

\subsection{Nucleic acid extraction}

DNA for quantitative PCR was extracted from large membrane filters $(142 \mathrm{~mm})$ using a previously established sodium chloride-Tris-EDTA (STE) method (Fuhrman et al., 1988; Pascoe and Hicks, 2004). Cells were lysed in STE buffer, generating a crude extract. The extract was rinsed with ethanol followed by protein removal using phenol:chloroform:isoamyl alcohol (25:24:1). Lipid extraction was performed on ethanol rinsed extract using chloroform:isoamyl alcohol (24:1). Purified extracts were stored in Tris-EDTA buffer at $-80^{\circ} \mathrm{C}$ until needed. Approximately $52 \%$ of added DNA was recovered during this extraction procedure. This recovery was used to correct qPCR results.

\subsection{Quantitative PCR of the archaeal 16S rRNA gene}

Quantitative PCR (qPCR) analyses utilized the Brilliant II SybrGreen Master ${ }^{\circledR}$ Mix system (Stratagene). Forward, Parch519F (5' CAG CCG CCG CGG TAA 3'), and reverse, Arch915R (5' GTG CTC CCC CGC CAA TTC CT $3^{\prime}$ ), PCR primers were used to amplify the archaeal 16S rRNA gene from picoplankton DNA (cf. Wuchter et al., 2006). The qPCR cycling profile held at $95^{\circ} \mathrm{C}$ for $5 \mathrm{~min}$, and then cycled 40 times at $95^{\circ} \mathrm{C}$ for $30 \mathrm{~s}, 63^{\circ} \mathrm{C}$ for $30 \mathrm{~s}, 72^{\circ} \mathrm{C}$ for $30 \mathrm{~s}$, and acquired data after holding at $81^{\circ} \mathrm{C}$ for $15 \mathrm{~s}$. Melt curves were generated by ramping temperature from 72 to $95^{\circ} \mathrm{C}$ by $1{ }^{\circ} \mathrm{C}$ steps (Wuchter et al., 2006). A 16S rDNA fragment amplified from an archaeal clone (SU10h3a) previously isolated from Lake Superior (Keough et al., 2003) was used to construct standard curves to calculate the number of archaeal 16S rRNA gene copies in samples.

\section{RESULTS}

\subsection{Temperature pattern of the water column of Lake Superior}

Our thermistor data show that Lake Superior surface waters experienced a wide range of water temperatures during the 3-year deployment (Fig. 2). The year 2006 stands out as an exceptionally warm year compared to 2007 and 2008, with temperatures at $17 \mathrm{~m}$ water depth increasing during summer to above $15^{\circ} \mathrm{C}$ compared to $\sim 11^{\circ} \mathrm{C}$ in 2007 and 2008 (Fig. 2). Fig. 2 clearly shows the dimictic nature of Lake Superior; the water column mixes twice a year in winter and in early summer. Thermal stratification starts around July with strongest stratification in August, after which mixing deepens the thermocline in September to November before reaching temperatures of $4{ }^{\circ} \mathrm{C}$ and overturning in mid/late December. In winter, the whole water column cools down to temperatures below $4{ }^{\circ} \mathrm{C}$ before inverse thermal stratification sets in and ice formation commences in late winter. In spring, winter stratification is broken down and the whole water column cools to $1-2{ }^{\circ} \mathrm{C}$ as a result of vertical mixing of the water column and eventually warms to $4{ }^{\circ} \mathrm{C}$. Warmer atmospheric temperatures in 2006 resulted in a short inverse stratification season in 2006 compared to 2007 and 2008. The duration of the summer stratification period at our study site was less sensitive to the temperature changes among the three annual cycles. 

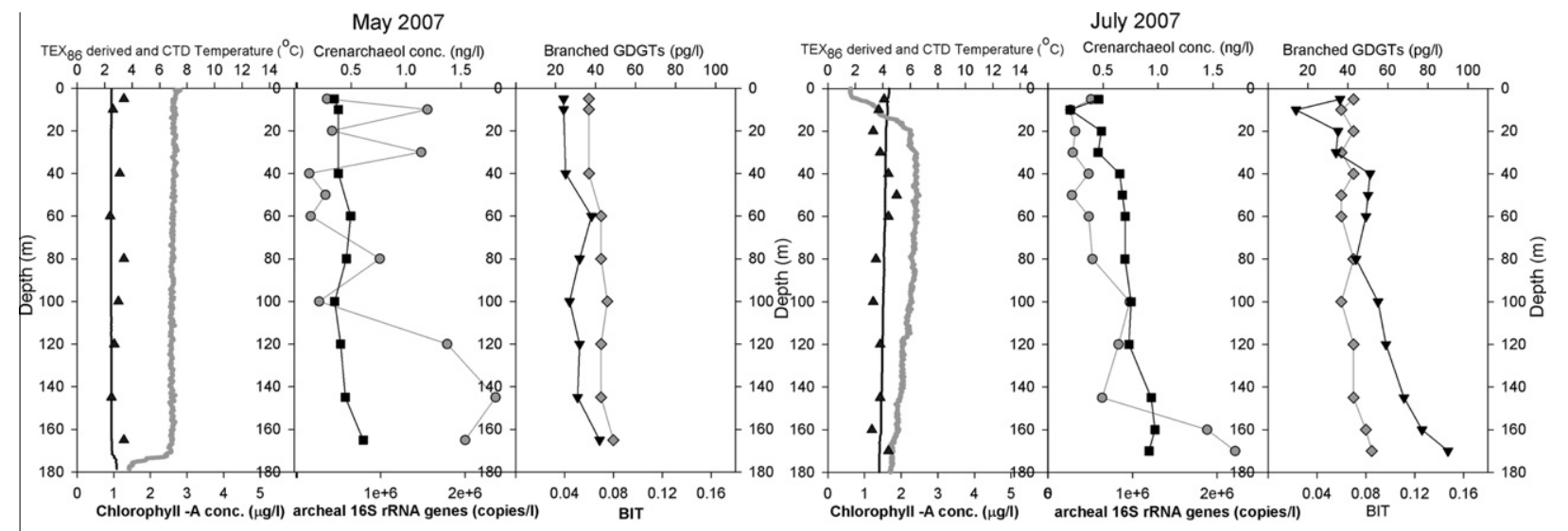

August 2007

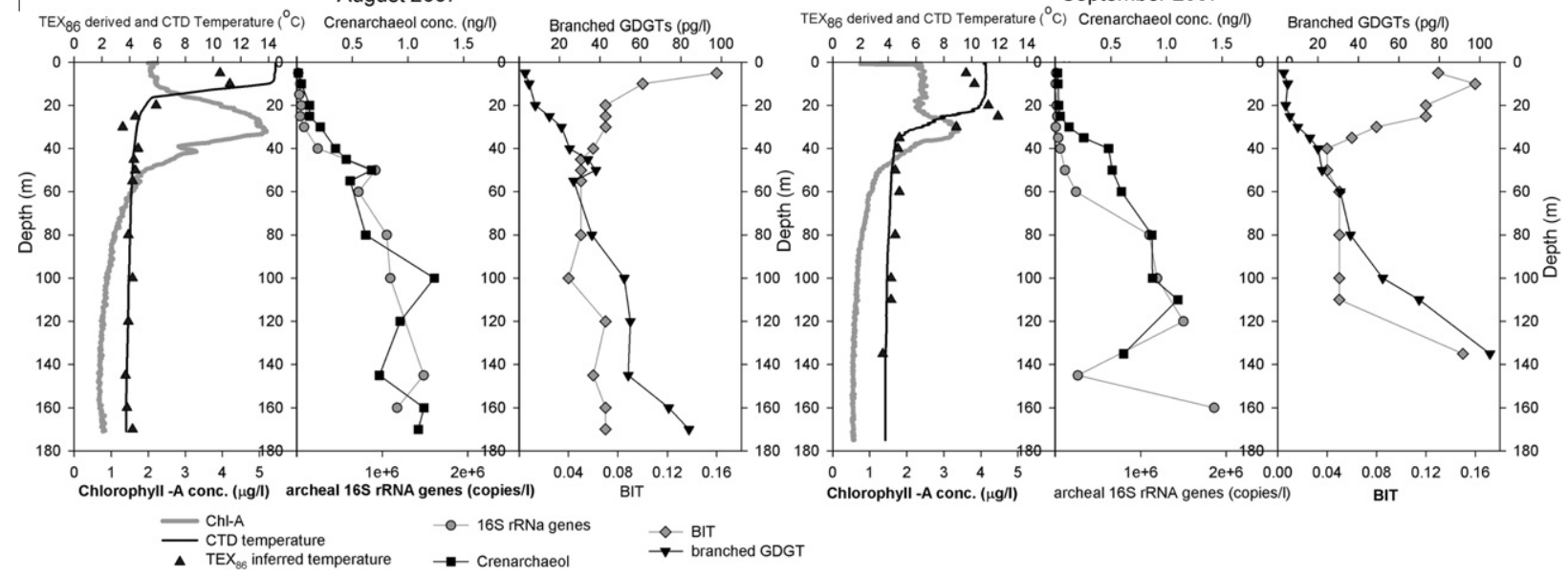

Fig. 3. Vertical profiles of $\mathrm{TEX}_{86}$ inferred water temperature from SPM and CTD measured water temperature, chlorophyll-a concentration, crenarchaeol concentration, archaeal 16s RNA gene copies and branched GDGT abundances and BIT values in SPM. TEX ${ }_{86}$ derived temperatures from SPM show good agreement with the in situ water temperatures where the SPM was sampled.

The vertical temperature structure as measured by the CTD in Lake Superior shows a large temperature variation between the cruises performed in 2007 (Fig. 3). In May 2007 a well-mixed water column was observed with temperatures ranging from $2.5^{\circ} \mathrm{C}$ at the surface to $2.9^{\circ} \mathrm{C}$ close to the sediment water interface (Fig. 3). In July 2007, a stable stratification was not yet established as water temperatures showed no clear indication of a thermocline (Fig. 3). Water temperatures ranged from $4.5^{\circ} \mathrm{C}$ at the surface to $3.8^{\circ} \mathrm{C}$ close to the sediment water interface. In August 2007, a well-established thermocline between 12 and $21 \mathrm{~m}$ depth was observed (Fig. 3). Water temperatures range from $14.4^{\circ} \mathrm{C}$ at the surface to $3.7^{\circ} \mathrm{C}$ in the hypolimnion close to the sediment water interface. In September 2007, a deeper thermocline compared to August was observed. Water temperatures were $11{ }^{\circ} \mathrm{C}$ at the surface and $\sim 3.8^{\circ} \mathrm{C}$ in the hypolimnion. The thermocline was located between 20 and $30 \mathrm{~m}$ depth (Fig. 3).

\subsection{Chlorophyll-a concentrations in the water column of Lake Superior}

During May 2007 a nearly uniform distribution of chlorophyll-a concentration throughout the water column was observed with a range of $2.7 \mu \mathrm{g} / \mathrm{L}$ near the surface to $2.5 \mu \mathrm{g} / \mathrm{L}$ at $170 \mathrm{~m}$ depth (Fig. 3). In July 2007, lowest chlorophyll-a concentrations $(\sim 0.6 \mu \mathrm{g} / \mathrm{L})$ were observed near the surface, increasing to $\sim 20 \mathrm{~m}$ depth below which chlorophyll-a concentrations remain stable at $\sim 2.4 \mu \mathrm{g} / \mathrm{L}$ to $\sim 70 \mathrm{~m}$ depth (Fig. 3). Below $70 \mathrm{~m}$, chlorophyll-a concentrations decreased with depth to $\sim 1.8 \mu \mathrm{g} / \mathrm{L}$ close to the sediment water interface. In August 2007, chlorophyll-a concentrations were low at the surface and increased with depth to a deep chlorophyll maximum (DCM) of $5.1 \mu \mathrm{g} / \mathrm{L}$ at $\sim 31 \mathrm{~m}$ water depth. Below the DCM, chlorophyll concentrations decreased with depth to $\sim 0.6 \mu \mathrm{g} / \mathrm{L}$ (Fig. 3). In September 2007, chlorophyll-a concentrations were $\sim 2.4 \mu \mathrm{g} / \mathrm{L}$ from the surface to $\sim 21 \mathrm{~m}$ water depth, below which chlorophyll-a concentrations increase to a DCM at $\sim 32 \mathrm{~m}$ and then decrease to a background concentration of $0.6 \mu \mathrm{g} / \mathrm{L}$ in deeper waters (Fig. 3).

\subsection{Archaeal 16S rRNA gene copies in SPM}

Quantification of total archaeal 16S rRNA gene copy numbers in May 2007 showed a large variation among depths with a range of $4-15 \times 10^{5}$ gene copies/L from 5 to $40 \mathrm{~m}, 2-10 \times 10^{5}$ gene copies/L from 45 to $100 \mathrm{~m}$ and 
1.7-2.4 $\times 10^{6}$ gene copies/L from 120 to $165 \mathrm{~m}$ (Fig. 3 ). In July 2007, archaeal 16S rRNA gene abundances were more stable with a range from 2.6 to $22 \times 10^{5}$ gene copies/L with highest copy numbers again occurring in the deep hypolimnion (Fig. 3). In August 2007, low amounts of archaeal gene copies (average $3.1 \times 10^{4}$ gene copies/L) were measured above the thermocline, with increasing abundances observed with depth below the thermocline to an average of $1.20 \times 10^{6}$ gene copies/L for water depths between 50 and $165 \mathrm{~m}$ (Fig. 3). In September 2007, we observed a similar trend of low archaeal gene abundances (average $1.6 \times 10^{4}$ gene copies/L) above the thermocline, with an increase below the thermocline to an average of $1.2 \times 10^{6}$ gene copies/L at depths greater than $80 \mathrm{~m}$ (Fig. 3).

\subsection{Isoprenoid GDGTs and $\mathrm{TEX}_{86}$ in SPM of Lake Superior}

Isoprenoid GDGTs in SPM of Lake Superior were dominated by GDGT-0 and crenarchaeol, which together make up $\sim 95 \%$ of the total isoprenoid GDGTs. A cross plot of crenarchaeol versus (crenarchaeol + GDGT-0) concentrations shows a near one to two relationship (Fig. 4). The ratio of crenarchaeol/(crenarchaeol + GDGT-0) shows stable values of 0.47 for May 2007, and 0.50 in July 2007, and ranges from 0.48 to 0.53 in August 2007 and 0.47 to 0.57 in September 2007, with the highest ratios observed in SPM from the warm surface water during the stratified period and lowest ratios in SPM sampled from the coldest waters.

In May 2007, isoprenoid GDGT concentrations were fairly uniform with depth with a range of concentration of crenarchaeol from 0.35 to $0.60 \mathrm{ng} / \mathrm{L}$, GDGT- 0 concentrations from 0.39 to $0.68 \mathrm{ng} / \mathrm{L}$ and total isoprenoid GDGT concentration of $0.77-1.4 \mathrm{ng} / \mathrm{L}$, with highest concentrations at $170 \mathrm{~m}$ water depth (Fig. 3). In July 2007, concentrations were low near the surface $(0.20 \mathrm{ng} / \mathrm{L}$ for crenarchaeol and GDGT-0 and $0.42 \mathrm{ng} / \mathrm{L}$ for total isoprenoid GDGTs at

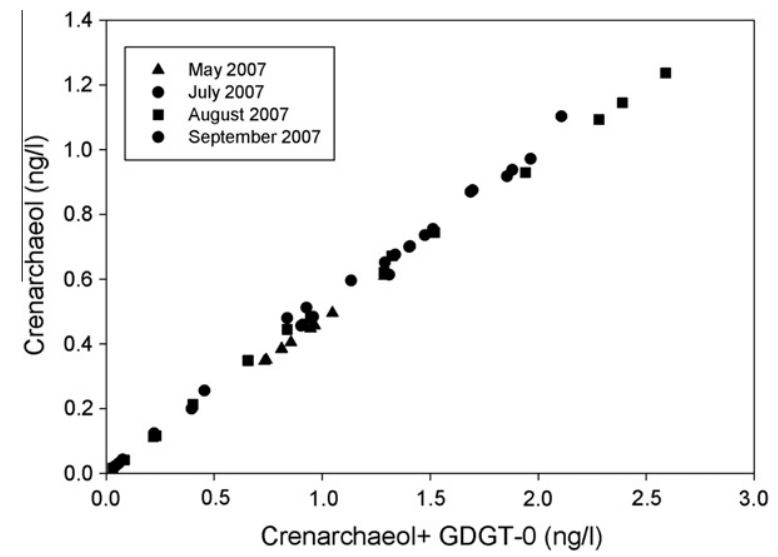

Fig. 4. Crossplot of crenarchaeol and (crenarchaeol + GDGT-0) concentrations in SPM showing that during all sampling periods there was a near 1:2 relationship between these two lipids, indicating a single source for the isoprenoid GDGTs in the water column. Based on the molecular community analyses done at the study site (Kish, 2010), we assume Thaumarchaeota are the major archaeal producers of GDGTs. $\sim 10 \mathrm{~m}$ water depth). Concentrations increased with depth to a maximum concentration of $1.0 \mathrm{ng} / \mathrm{L}$ for crenarchaeol and GDGT-0 and $2.1 \mathrm{ng} / \mathrm{L}$ for total isoprenoid GDGTs at $160 \mathrm{~m}$ water depth (Fig. 3). In August 2007, concentrations ranged from $\sim 0.02$ to $1.2 \mathrm{ng} / \mathrm{L}$ for crenarchaeol, 0.01-1.4 ng/L for GDGT-0 and 0.03-2.7 ng/L for total isoprenoid GDGTs, with low concentrations observed above the thermocline (Fig. 3); below the thermocline concentrations increased (Fig. 3). A similar pattern of vertical distribution of concentrations was observed during September 2007; concentrations were low in the epilimnion (average crenarchaeol concentration $\sim 0.03 \mathrm{ng} / \mathrm{L}, \quad$ GDGT-0 $\sim 0.02 \mathrm{ng} / \mathrm{L}$ and total isoprenoid GDGT $\sim 0.06 \mathrm{ng} / \mathrm{l}$ ), and increased below the thermocline to maximum concentrations in the hypolimnion $(\sim 0.87 \mathrm{ng} / \mathrm{L}$ for crenarchaeol, $0.83 \mathrm{ng} / \mathrm{L}$ for GDGT-0 and $1.7 \mathrm{ng} / \mathrm{L}$ for total isoprenoid GDGTs for depths $>80 \mathrm{~m}$ ) (Fig. 3). We note that the concentrations reported here might represent underestimations as we used a $0.7 \mu \mathrm{m}$ filter, which has been suggested to be less efficient in filtering archaeal cells (Huguet et al., 2010). However, we only analyzed core GDGTs (see Methods), which are predominantly fossil and therefore likely attached to larger aggregates and minerals. Indeed, Herfort et al. (2007) found for North Sea waters that $90 \%$ of core GDGTs was recovered using a $0.7 \mu \mathrm{m}$ filter, probably due to a decreasing pore size of the filter due to clogging with particulate matter.

In May 2007, $\mathrm{TEX}_{86}$ values throughout the water column were quite stable with a range of $0.30-0.31$, which if transferred into $\mathrm{TEX}_{86}$ derived temperatures according to the Powers et al. (2010) calibration yields temperatures of ca. $3{ }^{\circ} \mathrm{C}$ (Fig. 3). In July 2007, slightly higher $\mathrm{TEX}_{86}$ values with a range of $0.31-0.34$ are observed, which indicates temperatures between $\sim 3$ and $5{ }^{\circ} \mathrm{C}$, without a clear pattern between surface and deeper water (Fig. 3). In August and September 2007, there was a wider range of TEX $_{86}$ values (0.31-0.46) with highest $\mathrm{TEX}_{86}$ values corresponding to water masses from above the thermocline and lower $\mathrm{TEX}_{86}$ values from water masses below the thermocline. $\mathrm{TEX}_{86}$ derived temperatures range between 3 and $12{ }^{\circ} \mathrm{C}$, with a pattern similar to the actual thermal structure of the water column at these times (Fig. 3).

\subsection{Branched GDGTs and BIT values in SPM}

In May 2007, branched GDGT concentrations in SPM were always low with a range of $24-42 \mathrm{pg} / \mathrm{L}$, with highest concentration observed close the sediment water interface (Fig. 3). The BIT index showed a small range of 0.06 0.08 with highest BIT values observed in the deepest water. In July 2007, branched GDGT concentrations were more variable with a range of $14-90 \mathrm{pg} / \mathrm{L}$ with the highest abundance at the deepest sampling depth. BIT values range from 0.06 to 0.08 with the maximum values occurring at the same depth as where the highest branched GDGT concentrations were observed (Fig. 3). In August 2007, branched GDGT concentrations in SPM ranged from 3 to $84 \mathrm{pg} / \mathrm{L}$ (Fig. 3) with the lowest concentrations in the epilimnion and increasing concentrations with depth in the hypolimnion, with the highest concentration at the deepest sampling 
depth. The BIT index ranges from 0.04 to 0.16 with the highest BIT values in the epilimnion, which was caused by the low crenarchaeol concentration in the surface water. BIT values decrease with depth from 30 to $100 \mathrm{~m}$ depth, after which BIT values increase with depth toward the lake bottom (Fig. 3). The largest range in concentrations of branched GDGTs in SPM was observed in September 2007 with a range 3-105 pg/L (Fig. 3). As in August, the

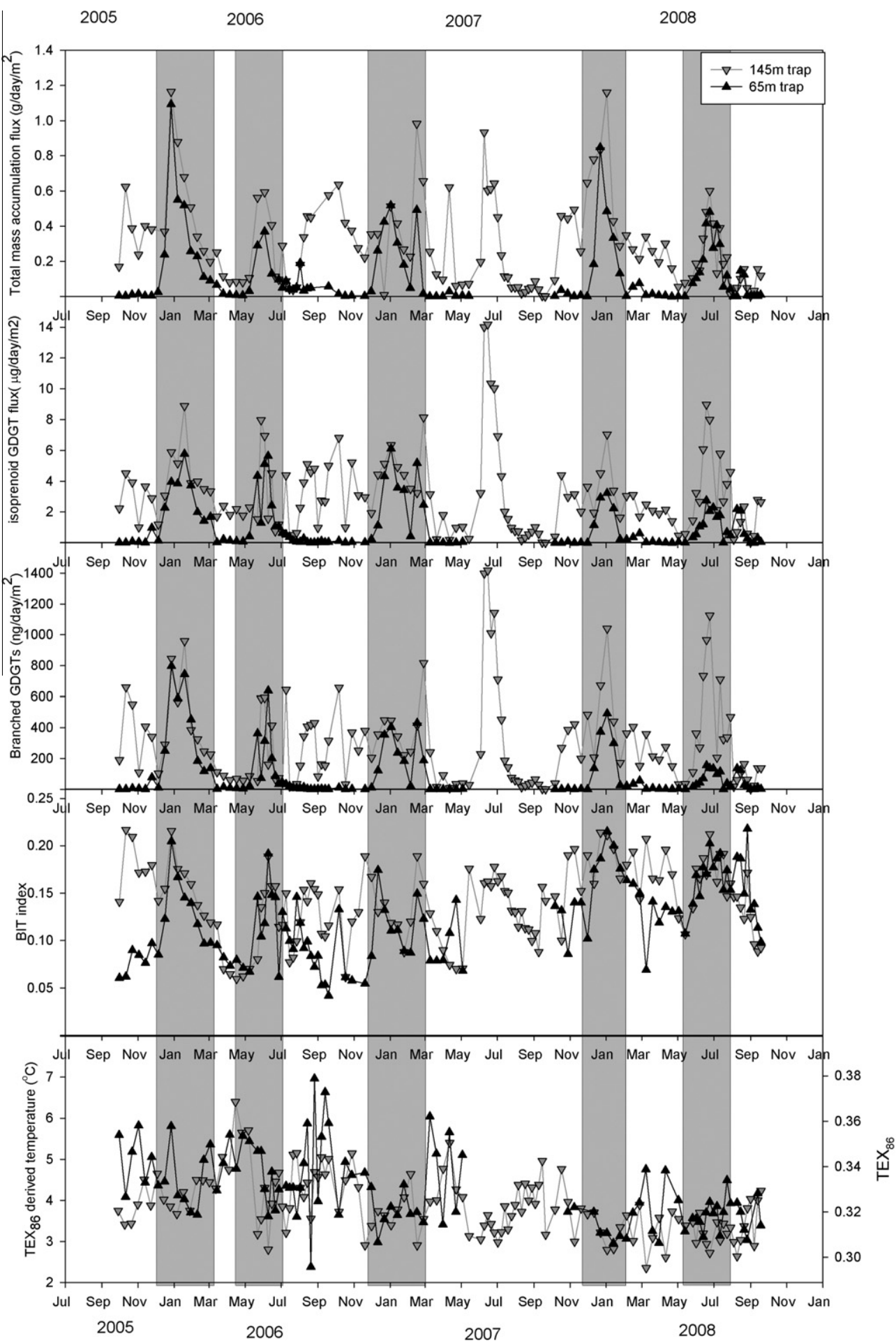

Fig. 5. Fluxes in the sediment traps collected at 65 and $145 \mathrm{~m}$ depth during the period from 2005 to 2008 . Shaded areas depict periods when all fluxes are high in both traps. The $65 \mathrm{~m}$ trap malfunctioned during the May 2007 deployment, resulting in no data between June and end of September 2007 for this trap. Overall measured fluxes show a similar seasonal pattern with two periods of high flux occurring in winter and spring. During these high flux periods BIT values increase in the top trap, but this is less obvious in the deeper trap. 
lowest abundances of branched GDGTs were observed within the epilimnion. In the hypolimnion, branched GDGT concentrations increased with depth. BIT values range from 0.04 to 0.16 , again highest BIT values were observed in the epilimnion (Fig. 3), due to relatively low crenarchaeol concentrations in the surface water. BIT values decrease between 30 and $80 \mathrm{~m}$, due to higher crenarchaeol concentrations in the hypolimnion (Fig. 3). The BIT value at $135 \mathrm{~m}$ depth is substantially higher compared to the rest of the hypolimnion (Fig. 3).

\subsection{Fluxes and GDGT composition of settling particles}

In the $65 \mathrm{~m}$ sediment trap total mass fluxes ranged between 0.002 and $1.1 \mathrm{~g} \mathrm{~m}^{-2} \mathrm{day}^{-1}$ with two periods of increased flux over the annual cycle occurring from late December through February and in June-July with generally low accumulation throughout the rest of the year (Fig. 5). The deeper trap at $145 \mathrm{~m}$ revealed a large range of mass fluxes from 0.001 to $1.2 \mathrm{~g} \mathrm{~m}^{-2} \mathrm{day}^{-1}$ with the highest flux periods occurring in the same two periods as in the $65 \mathrm{~m}$ trap, but additionally shows multiple other periods of increased mass accumulation, which are not visible in the top sediment trap data.

The isoprenoid GDGT distribution in sediment trap material is dominated by crenarchaeol $(47 \pm 2 \%)$ followed by GDGT-0 (40 $\pm 3 \%$ ), with all other isoprenoid GDGTs representing only $13 \pm 3 \%$ of the total isoprenoid GDGT distribution combined. Isoprenoid GDGT fluxes in the sediment traps show trends similar to those observed in total mass flux (Fig. 5). In the $65 \mathrm{~m}$ sediment trap isoprenoid GDGT fluxes range from 2 to $6 \mu \mathrm{g} \mathrm{m}^{-2}$ day $^{-1}$ with high and low fluxes at the same dates as the mass flux. Sometimes the maximum in isoprenoid GDGT flux trails the mass accumulation by one sample period, but this is not consistently the case. In the $145 \mathrm{~m}$ trap isoprenoid GDGT flux ranges from 0.1 to $14 \mu \mathrm{g} \mathrm{m}^{-2} \mathrm{day}^{-1}$; fluxes are generally higher than those observed in the $65 \mathrm{~m}$ trap (Fig. 5). The trend in total isoprenoid GDGT fluxes again shows a strong resemblance to the mass accumulation flux in the same trap. Overall the peaks in isoprenoid GDGT fluxes appear to occur at the same time or with a slight delay of one sampling period (corresponding to 11 days in the winter deployment or 6 days in the spring deployment) relative to the peak in the mass accumulation flux.

$\mathrm{TEX}_{86}$ values in the sediment trap material ranged between 0.30 and 0.38 in the $65 \mathrm{~m}$ trap and 0.30 and 0.37 for the $145 \mathrm{~m}$ trap without a clear seasonal pattern (Fig. 5). Based on the observed fluxes and $\mathrm{TEX}_{86}$ values in sinking organic matter, it is possible to calculate a flux weighted averaged $\mathrm{TEX}_{86}$ value, which would be analogous to the composition of sediment formed over time from the sinking particulate matter. Flux weighted averaged TEX $_{86}$ values are 0.33 for the top and 0.32 for the bottom trap. Transferring $\mathrm{TEX}_{86}$ values into temperatures using the Powers et al. (2010) calibration yields temperatures that span between 2.4 and $7.0^{\circ} \mathrm{C}$ in the shallow trap and 2.4 $6.4^{\circ} \mathrm{C}$ in the deep trap (Fig. 5). Flux weighted average temperatures are 4.0 and $3.7^{\circ} \mathrm{C}$ for the top and bottom traps, respectively. Surface sediments from the sample site yield an average $\mathrm{TEX}_{86}$ value of $\sim 0.32$, which represents a water temperature of $3.6^{\circ} \mathrm{C}$.

Branched GDGTs generally constitute a small (ca. 8\%) portion of the total GDGT flux. Branched GDGT fluxes in the sediment traps range from 0.04 to $800 \mathrm{ng} \mathrm{m}^{-2}$ day $^{-1}$ for the $65 \mathrm{~m}$ trap and 0.03 to $1400 \mathrm{ng} \mathrm{m}^{-2} \mathrm{day}^{-1}$ for the deeper trap (Fig. 5). Trends of branched GDGTs resemble both the total mass accumulation and the isoprenoid GDGT flux. The $65 \mathrm{~m}$ trap shows two periods of higher branched GDGT flux, while the deeper trap shows more periods of increased branched GDGT flux (Fig. 5). Maxima in branched GDGT fluxes are observed to occur at the same time as the isoprenoid GDGT fluxes.

The BIT index in the sinking particles varies from 0.04 to 0.22 and 0.06 to 0.22 in the 65 and $145 \mathrm{~m}$ trap, respectively (Fig. 5). Maximum BIT values in the top trap are also reflected in the deeper trap although more subtle; in the upper trap BIT values tend to increase and decrease together with the total mass accumulation flux. This trend is less visible in the deeper trap, although maximum BIT values do appear to coincide with periods of maximum mass accumulation flux. The flux weighted averaged BIT value is 0.15 for both traps, which is exactly the same value as observed in surface sediments from the study site.

\section{DISCUSSION}

\subsection{Vertical distributions of archaeal genes and GDGT lipids in Lake Superior}

The primers utilized for qPCR in our study are not specific to Thaumarchaeota, but amplify archaeal $16 \mathrm{~S}$ rRNA genes that could be produced by all archaea. Therefore, there is a possibility that the gene abundance profiles may include archaea other than the Thaumarchaeota. However, a molecular ecological study utilizing cloning and sequencing on the same water samples from the stratified period as analyzed here, observed that the archaeal population in the water column is largely comprised of Thaumarchaeota species that phylogenetically are closely related to the Thaumarchaeote Nitrosopumilus maritimus (Kish, 2010), a marine isolate (Konneke et al., 2005). Euryarchaeota are observed to comprise at most $15 \%$ of total archaea present in the deep hypolimnion near the sediment water interface, and there were no Euryarchaeota species observed in the epilimnion (Kish, 2010). Furthermore, during all sampling periods there is near one to two covariance between crenarchaeol and (crenarchaeol + GDGT-0) lipid concentrations (Fig. 4), suggesting a common, thaumarchaeotal, origin for these lipids in the water column since crenarchae$\mathrm{ol}$ is the characteristic membrane lipid for Thaumarchaeota (e.g. Sinninghe Damsté et al., 2002; De La Torre et al., 2008; Pitcher et al., 2010, 2011). Thus, it seems that most of the isoprenoid GDGTs in the Lake Superior water column are derived from Thaumarchaeota. This observation differs from observations in Lake Challa, where characterization of $16 \mathrm{~S}$ rRNA gene sequences in SPM in water column indicated a probable additional archaeal source of GDGT-0 and GDGT-2 in the anoxic water column or sediment (Sinninghe Damsté et al., 2009). 
The vertical profile of the archaeal $16 \mathrm{~S}$ rRNA gene abundance in Lake Superior suggests that archaea, predominantly Thaumarchaeota, are distributed throughout the water column of Lake Superior during isothermal conditions when the lake is well mixed, but mainly reside in the hypolimnion (i.e. below $20-40 \mathrm{~m}$ ) during times of thermal stratification. Although there are indications that over the annual cycle resuspension and lateral transport of particles may play a large role at this site in Lake Superior (discussed below), none of the SPM sampling periods coincided with times of significant resuspension. Instead, isoprenoid GDGT lipid profiles show a pattern similar to that of the 16s rRNA gene abundance, suggesting that the GDGTs are potentially derived from recently living archaea. This is perhaps somewhat surprising considering that core GDGTs are by definition of fossil origin resulting from removal of polar head groups when intact polar GDGTs degrade after cell death (White et al., 1979; Harvey et al., 1986; Lipp et al., 2008; Schouten et al., 2008; Huguet et al., 2010). However, if the degradation of intact GDGTs is relatively rapid upon cell death, it would result in a correspondence between core GDGTs and archaeal 16S rRNA gene abundances. During summer thermal stratification both crenarchaeol and archaeal 16S rRNA genes were most abundant in the hypolimnion at depths $>40 \mathrm{~m}$, below the depth of the deep chlorophyll maximum (DCM). Although in low concentrations, isoprenoid GDGTs and archaeal 16S rRNA genes are present in the epilimnion at this time (Fig. 3). This distribution differs from the non-stratified period when both isoprenoid GDGT and archaeal 16S rRNA genes abundances are observed to be quite constant throughout the water column with only a marginal increase with depth. These results suggest that the preferred location of Thaumarchaeota in the water column of Lake Superior during the thermally stratified period is in the colder hypolimnion at depths below the DCM.

One thing to consider is that suspended particulate matter was obtained using filters with different pore sizes ( $0.2 \mu \mathrm{m}$ for $16 \mathrm{~S}$ rRNA and $0.7 \mu \mathrm{m}$ fore core GDGT lipids). As the size of Thaumarchaeota is typically well below $1 \mu \mathrm{m}$ (Konneke et al., 2005), an unknown proportion of the achaeal population could have been captured by the $0.2 \mu \mathrm{m}$ filter and used for 16S rRNA analyses, but may have passed through the $0.7 \mu \mathrm{m}$ filter. Herfort et al. (2007) analyzed GDGT concentrations in the North Sea with sequential filters of 0.7 and $0.2 \mu \mathrm{m}$ pore size and observed and recovered only $<5 \%$ of the total GDGTs on the $0.2 \mu \mathrm{m}$ filters. This observation may be explained by the high turbidity in this coastal sea, where particulate matter can rapidly clog filters, effectively reducing the nominal pore size. However, Pitcher et al. (2011) filtered biomass from a Thaumarchaeota enrichment culture and recovered only $12 \%$ on a $0.7 \mu \mathrm{m}$ compared to a $0.2 \mu \mathrm{m}$ GFF filter. It is therefore likely that in Lake Superior with its oligotrophic waters some of the core GDGT lipids were lost through using large pore size filters; however, it is impossible to say exactly how much. Filtration efficiency changes with depth, e.g. due to turbidity changes associated with depth of primary production in the water column of Lake Superior could potentially have caused mismatches between the archaeal 16S rRNA and core GDGT numbers; however, the observed patterns in the water column were generally similar suggesting that different filtration efficiencies did not play a large role.

\section{2. thaumarchaeotal derived GDGTs in settling particles}

The observed trends in settling fluxes of isoprenoid GDGT lipids shows a strong resemblance to the timing and trend of fluxes of both branched GDGTs and the total mass accumulation (Fig. 5). In the top sediment trap (located at $65 \mathrm{~m}$ depth) there were two main periods in the annual cycle when all measured fluxes were observed to be high (January-March and the month of June). In the top trap these two periods comprise $83 \%$ of the annual GDGT or total mass accumulation in the sediment trap (Fig. 5). Fluxes in the deeper sediment trap (at $145 \mathrm{~m}$ depth) were almost always higher than in the top sediment trap, and show much more variability and additional periods of higher flux throughout the year (Fig. 5). As a result of these additional periods of increased flux in the deeper sediment trap the two main periods as observed in the top trap only comprise $51 \%$ of the total accumulation in the deep sediment trap. The observed seasonal pattern of bulk accumulation in the sediment traps may have resulted from several different processes occurring in Lake Superior, including a spring diatom bloom or an influx of previously deposited particles that were originally produced in a shallower region of the lake that were resuspended and laterally transported towards the study site.

The period of increased flux that occurs in June corresponds with the timing of the spring diatom bloom in Lake Superior. During most of the year primary production in Lake Superior is limited by light availability, but diatoms bloom in June before the onset of thermal stratification (Guildford et al., 2000). A diatom bloom occurring at this time of the year could potentially cause the increase in the bulk accumulation flux as observed in the traps. Some supporting evidence for this can be seen in the results of preliminary microscopic analyses of bulk settling particles that were observed to contain large numbers of diatom tests from Stephanodiscus spp. A diatom bloom in Lake Superior would increase the amount of sinking particles in the water column, which could scavenge GDGT lipids from the water column, effectively increasing the transport of GDGT lipids out of the water column. However, we also observed that increased fluxes of GDGTs were associated with a slight increase in the BIT index, suggesting that branched GDGT lipids may be more effectively scavenged compared to isoprenoid GDGTs. There is no evidence that preferential scavenging of branched GDGTs would result from a diatom bloom. Furthermore, the winter peak in bulk fluxes is not related to a diatom bloom as it occurs at a time when primary production is very low due to the low water temperatures and low light availability.

Previous sediment trap studies in the Laurentian Great Lakes, including Lake Superior, have observed that highest sediment fluxes in these lakes occur during the unstratified periods. This is generally explained by storm induced resuspension occurring when these lakes are not thermally stratified (Baker et al., 1991; Eadie et al., 1984). Mixing of the 
water column is confined to the epilimnion during thermal stratification, allowing recently produced particles to settle down and accumulate into a sediment boundary layer at locations where no net sediment deposition occurs over the annual cycle (Baker and Eisenreich, 1989). With subsequent break down of thermal stratification and mixing of the water column, the particles that make up the sediment boundary layer (SBL) are easily resuspended and transported towards the deeper, more quiescent depositional regions of the lake where they settle out of the water column (Baker and Eisenreich, 1989). Although particle dynamics in Lake Superior during winter time are poorly studied, relatively strong bottom currents in excess of $40 \mathrm{~cm} \mathrm{~s}^{-1}$ have been observed in Lake Superior (Flood, 1989), and a combination of bottom currents and waves generated at high wind speeds was shown to cause resuspension and offshore transport of particles during the winter season in Lake Superior (Hawley, 2000). Furthermore, a recent ${ }^{14} \mathrm{C}$ study in the western arm of Lake Superior observed that suspended POC in the water column was typically older than co-occurring DOC, which is most likely caused by resuspension of lake sediments (Zigah et al., 2011). This process may explain our observations of maximum bulk fluxes that occur in winter and spring, as these periods of increased flux occur at a time when Lake Superior is isothermal and mixing and thus sensitive to storm induced resuspension and lateral transport.

Resuspension and lateral transport of previously deposited particles toward our sample site (i.e., sediment focusing) could very well bring in allochthonous fossil GDGT lipids that were previously produced and deposited at a shallower location in the lake. Although we do not have supporting evidence to confirm that this process is actually dominant during these periods, it would potentially explain the observed covariance of all measured fluxes. Additionally it would provide a mechanism for higher BIT values observed during these periods as the particles transported towards the site are likely derived from a more near-shore location with a higher proportion of soil organic matter input. An influx of particles to the study site could also enhance particle scavenging, and therefore fluxes, of locally produced isoprenoid GDGTs. However, isoprenoid GDGTs that settle out of the water column during the winter period of increased flux do not appear to capture the observed decrease in water temperatures recorded by thermistors throughout the water column during this time (Fig. 6) (discussed below). This lack of temperature correspondence suggests that particle scavenging may not be dominant. The strong covariance of the measured fluxes to sediment traps more likely indicates a significant role for influx of allochthonous particles from shallower location in the lake towards the study site. This clouds the interpretation of observed isoprenoid fluxes over the annual cycle as reflecting periods of Thaumarchaeota production.

The observed fluxes of isoprenoid GDGTs in Lake Superior $\left(0.1-14 \mu \mathrm{g} \mathrm{m}^{-2} \mathrm{day}^{-1}\right)$ are mostly higher than the range $\left(0.1-0.4 \mu \mathrm{g} \mathrm{m}^{-2}\right.$ day $\left.^{-1}\right)$ that was observed in Lake Lucerne (Blaga et al., 2011), but lower than those observed in Lake Baikal (1-62 and 4-22 $\mu \mathrm{g} \mathrm{m}^{-2}$ day $^{-1}$ ) (Escala Pascual, 2009) and Lake Challa $\left(\sim 5-25 \mu \mathrm{g} \mathrm{m}^{-2} \mathrm{day}^{-1}\right)$

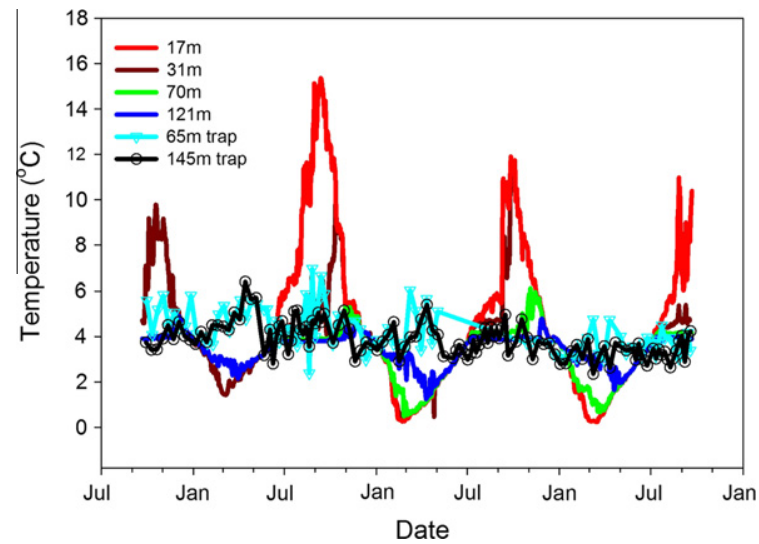

Fig. 6. $\mathrm{TEX}_{86}$ derived temperatures from sediment traps compared to measured water temperatures at different depths. The TEX $\mathrm{X}_{86}$ derived temperatures from the traps do not follow the seasonality pattern of water temperatures as measured at different water depths throughout the water column.

(Sinninghe Damsté et al., 2009). The GDGT fluxes observed in the deeper trap during most of the annual cycle are higher than observed in the top trap, and although the main trend of maximum fluxes in the top trap is clearly present in the deep trap, there is greater variability in the deeper trap. Higher isoprenoid GDGT fluxes in the deep trap relative to the top trap may indicate mid-depth production of GDGTs. This interpretation agrees with the observation that Thaumarchaeota are also present in significant abundance below the depth of the top sediment trap $(65 \mathrm{~m})$. However the higher observed overall fluxes in the deeper sediment trap are more likely the result collecting a larger fraction of resuspended sedimentary material, as the deeper trap is located substantially closer to the sediment water interface relative to the top sediment trap.

\subsection{TEX $_{86}$ values and inferred temperatures in Lake Superior}

Profiles of $\mathrm{TEX}_{86}$-reconstructed temperatures from SPM in Lake Superior show a remarkable resemblance to the in situ thermal structure of the water column at the time of sampling during both thermally stratified and well mixed periods (Fig. 3). Additionally TEX $_{86}$ values from SPM sampled from the epilimnion yield higher water temperatures, indicating that the Thaumarchaeota in the epilimnion, although only present in low abundance, produce core GDGTs that reflect in situ temperatures. The apparent accuracy of $\mathrm{TEX}_{86}$ inferred water temperatures from SPM supports our hypothesis that the isoprenoid core GDGTs measured were mainly derived from recently lysed archaeal cells. Although these GDGT lipids are of "fossil" origin, there is apparently a relatively quick turnover (on the order of days to weeks) of these GDGT lipids in the water column of Lake Superior.

These observations of a good correspondence between observed $\mathrm{TEX}_{86}$ values and instrumentally measured temperatures may be somewhat surprising considering as results from the sediment trap suggest a large role of 
suspended and laterally transported particles over the annual cycle. However, further investigation of the sediment trap data near the periods when water filtration for suspended particles took place shows that sampling occurred during periods when the influence of resuspended and laterally transported particles was relatively low. The observations in the suspended particulate matter therefore suggest that these lipids were not old resuspended lipids, but instead point toward a recent origin of the core GDGTs in the water column.

Recent observations in the marine core top $\mathrm{TEX}_{86}$ calibrations documented a nonlinear response of the TEX $\mathrm{T}_{86}$ at temperatures $<5{ }^{\circ} \mathrm{C}$ (Kim et al., 2008), which lead to the introduction of new calibrations for inferring temperatures from distributions of isoprenoid GDGTs (Kim et al., 2010). Due to a lack in data points from lakes covering this temperature zone in the lacustrine calibration (Powers et al., 2010), it is not possible to determine if this non-linearity $<5{ }^{\circ} \mathrm{C}$ also occurs in lakes. However, a cross plot of $\mathrm{TEX}_{86}$ values from SPM and in situ temperatures from $<5{ }^{\circ} \mathrm{C}$ appears to show a linear relationship that is consistent with the Powers et al. (2010) lacustrine calibration (Fig. 7), therefore arguing against a nonlinear relationship of the $\mathrm{TEX}_{86}<5^{\circ} \mathrm{C}$ in lakes, though the data are sparse. Furthermore, applying the newly introduced $\mathrm{TEX}_{86}^{\mathrm{L}}$ (Kim et al., 2010) to the Lake Superior SPM from lower temperatures leads to unrealistically low temperatures that are consistently more than $7^{\circ} \mathrm{C}$ too low compared to the actual temperature of the water column. This could potentially indicate a difference in membrane adaptation of marine and lacustrine Thaumarchaeota in cold environments. Our observations are similar to those of Shevenell et al. (2011) whom in the Southern Ocean also observed a good correlation between $\mathrm{TEX}_{86}$ values at low temperatures in a local calibration and that application of the $\mathrm{TEX}_{86}^{\mathrm{L}}$ calibration yielded unrealistically cold inferred water temperatures.

During the thermally stratified period isoprenoid GDGTs appear to be mainly produced below the thermocline,

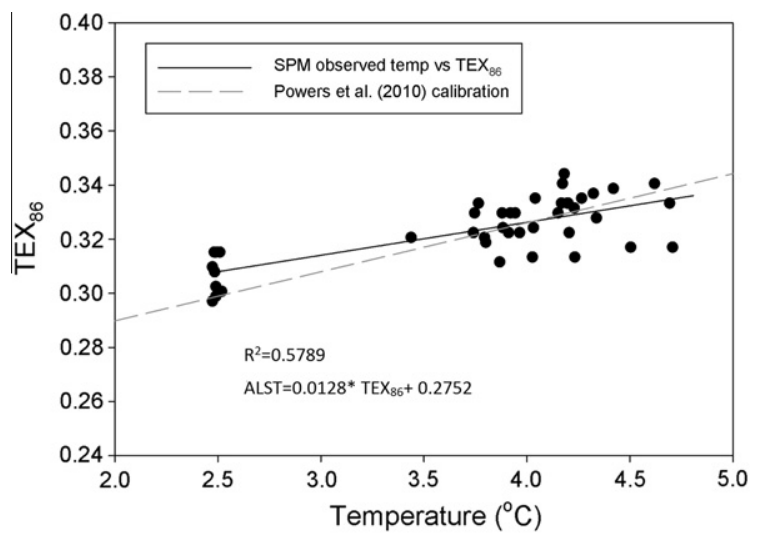

Fig. 7. A cross plot of $\mathrm{TEX}_{86}$ values determined in suspended particles from Lake Superior relative to observed water temperature at the depth the suspended particles were sampled show a linear relationship that is relatively consistent to the linear relationship of the Powers et al. (2010) lacustrine calibration. suggesting that the $\mathrm{TEX}_{86}$ likely reflects a sub thermocline/ hypolimnetic water temperature during this period. Although zooplankton grazing at the same study site in Lake Superior was documented to be the highest in the epilimnion, grazing was observed throughout the water column (max depth surveyed was $80 \mathrm{~m}$ ) (Seegers, 2009), thereby providing a potential sedimentary transport mechanism for both isoprenoid GDGT lipids produced above and below the thermocline. TEX ${ }_{86}$ values determined in settling particles from the thermally stratified period were relatively similar to $\mathrm{TEX}_{86}$ values obtained from samples of SPM sampled below thermocline. Thus, isoprenoid GDGTs settling from the epilimnion appear to be overwhelmed by a much larger contribution of isoprenoid GDGTs produced below the thermocline that reflect hypolimnetic water temperature. Over the entire annual cycle, however, the $\mathrm{TEX}_{86}$ signal that gets incorporated into sediments likely reflects some combination of the mean temperature of the hypolimnion when thermally stratified and the water temperature when the lake is mixing, as Thaumarchaeota are observed throughout the water column when the lake is mixing.

$\mathrm{TEX}_{86}$ inferred temperatures from settling particles collected in the sediment traps yield a relatively narrow range of $\mathrm{TEX}_{86}$ derived temperatures during the 3 year long study period (Fig. 5). TEX $_{86}$ derived temperatures range from 2.4 to $7{ }^{\circ} \mathrm{C}$ in the $65 \mathrm{~m}$ trap and $2.4-6.4{ }^{\circ} \mathrm{C}$ in the $145 \mathrm{~m}$ sediment trap with no observed temperature increase during the period of stratification. Overall, $\mathrm{TEX}_{86}$ derived temperatures from the sediment traps do not follow any of the seasonal changes in water temperatures as observed throughout the water column at different depths (Fig. 6). The $\mathrm{TEX}_{86}$ in settling particles from the winter period of increased flux did not capture an observed decline in water temperatures observed throughout the water column during this period (Fig. 6). One would expect to have observed an eventual decline in the $\mathrm{TEX}_{86}$ values over this period if the higher isoprenoid flux actually resulted from particle scavenging of recently locally produced isoprenoid GDGTs. The lack of a cooling trend in the TEX $_{86}$ values during the winter period may thus be circumstantial evidence that the GDGTs deposited at this time are older, allochthonous lipids that were transported towards the study site, or are recently produced GDGT lipids from other areas of the lake, that are reflecting mixing water temperatures.

Flux weighted average $\mathrm{TEX}_{86}$ inferred temperatures from settling particles from both traps are similar $\left(4.0^{\circ} \mathrm{C}\right.$ for the upper trap and $3.7^{\circ} \mathrm{C}$ for the deep trap) and are close to the $\mathrm{TEX}_{86}$ inferred temperature determined from surface sediments at the study site $\left(3.6^{\circ} \mathrm{C}\right)$. Unfortunately, the instrumentation on the nearby NOAA buoy, on which this study relied on for surface water temperature measurements, was not always online during the thermally stratified periods. However, several thermistors located on the mooring that recorded water temperatures over a range of different water depths during the length of the sediment trap deployment yield average water temperatures of which many are relatively close to the $\mathrm{TEX}_{86}$ inferred temperatures from the sediment traps: at $17 \mathrm{~m}$ water depth the average measured temperature is $4.7^{\circ} \mathrm{C}$, at $30 \mathrm{~m}$ it was $3.9^{\circ} \mathrm{C}$, at $70 \mathrm{~m} 3.4{ }^{\circ} \mathrm{C}$ and at $121 \mathrm{~m} 3.5^{\circ} \mathrm{C}$. All these temperatures 
are within the calibration error of the $\mathrm{TEX}_{86}$ temperature estimates, although the best agreement is observed for averaged water temperatures below depths of $31 \mathrm{~m}$.

Our study in Lake Superior observed that in the water column Thaumarchaeota are present throughout all depths when Lake Superior is mixing, while predominantly residing below depth of the thermocline (below $40 \mathrm{~m}$ depth) during the period of thermal stratification, suggesting that the $\mathrm{TEX}_{86}$ value in the sediment of Lake Superior likely reflects a combination of water temperatures during mixing/overturning and sub-thermocline temperatures over the annual cycle. As overturning water temperatures at the surface and those at depths below $40 \mathrm{~m}$ are essentially the same, the $\mathrm{TEX}_{86}$ of Lake Superior sediments is therefore likely recording the average water temperature for water below a depth of $40 \mathrm{~m}$.

Recently Blaga et al. (2011) also observed a sub-thermocline position of the Thaumarchaeota within Lake Lucerne, where at present day $\mathrm{TEX}_{86}$ values appear to mainly reflect the temperature from the sub-thermocline (below $50 \mathrm{~m}$ ). However, other studies in Lakes Lugano, Brientz (Bechtel et al., 2010), Challa (Sinninghe Damsté et al., 2009) and Kivu (Lliros et al., 2010) observed that Thaumarchaeota there reside in the epilimnion. Bechtel et al. (2010) further observed that in Lake Lugano and Lake Brientz TEX ${ }_{86}$ values in SPM show good agreement with the surface water temperatures of these lakes, which is in contrast to what was observed in Lake Superior.

The observations that the $\mathrm{TEX}_{86}$ in sediments among different lakes reflect temperatures from different parts of the water column may explain some of the observed scatter in the Powers et al. (2010) calibration. Additionally, it might explain why Blaga et al. (2009) in their European core tops study observed a higher correlation between $\mathrm{TEX}_{86}$ values and mean winter surface water temperatures compared to annual mean surface water temperatures. If in a portion of their lakes isoprenoid GDGT lipids were produced near the bottom or below the thermocline during the summer stratified period, the sedimentary $\mathrm{TEX}_{86}$ signal would be expected to be closer to a mean winter temperature rather than summer surface temperature.

\subsection{Application of the $\mathrm{TEX}_{86}$ as a paleotemperature proxy in Lake Superior}

The question remains of how sensitive a combination of mixing and hypolimnetic temperatures in Lake Superior would be to changes in atmospheric temperatures surrounding Lake Superior. While it is known that epilimnetic/surface water temperatures of lakes can be highly correlated with regional air temperatures and show a rapid and direct response to climate forcing, the mixing and sub-thermocline response to regional changes is slower and more complex (Adrian et al., 2009). On short time scales (months/years) the response of the hypolimnion may depend on the morphometry of the lake (Gerten and Adrian, 2001) and season (Robertson and Ragotzkie, 1990; Livingstone and Lotter, 1998; Straile et al., 2003). Different warming rates of the epilimnion and hypolimnion may result in a change of thermal stability and further affect the duration of summer stratification (Livingstone, 2003). The warming of the hypolimnion will have a subsequent effect on mixing temperatures, as overturning commences when epilimnetic and hypolimnetic water temperatures result in a small enough density difference so that wind activity can mix the water column. On longer time scales the hypolimnion will respond to changes in atmospheric temperature, although these may not be parallel to the annual evolution of atmospheric temperatures. Furthermore, due to the high thermal mass of the hypolimnion compared to the isolated epilimnion in Lake Superior, a warming or cooling of the hypolimnion in Lake Superior may have significant smaller amplitude relative to changes in atmospheric temperatures.

Utilizing $\mathrm{TEX}_{86}$ as a temperature proxy in Lake Superior may provide information about past temperatures in this region, but if the $\mathrm{TEX}_{86}$ in Lake Superior reflects a combination mixed and hypolimnetic temperatures the observed amplitude of temperature changes may be relatively small compared to the absolute changes in atmospheric temperatures. Thus, trends in $\mathrm{TEX}_{86}$ inferred temperatures in sediment records of Lake Superior, and probably similar lakes, are likely to reflect subsurface temperature variability rather than that of surface temperatures.

As in Lake Superior, it was documented in Lake Lucerne that Thaumarchaeota mainly resided at depths below the thermocline, and the $\mathrm{TEX}_{86}$ in settling particles mainly reflected a deep water (below $50 \mathrm{~m}$ depth) temperature (Blaga et al., 2011). However, an investigation of a gravity core from Lake Lucerne observed a possible effect of recent historic eutrophication and recovery of Lake Lucerne on the depth of production of thaumarchaeotal lipids (Blaga et al., 2011). TEX 86 values from before onset of eutrophication were higher relative to the more recent eutrophic and the present day oligotrophic state of the lake, although the instrumental record over this period shows no changes in temperatures during these periods. These inferred temperatures before onset of eutrophication in Lake Lucerne are still lower than annual mean surface water temperature, but were interpreted to indicate that the depth of Thaumarchaeota production during the original oligotrophic state of the lake was higher in the water column compared to the recent and present day depth of production of Thaumarchaeota (Blaga et al., 2011).

Compared to Lake Lucerne, Lake Superior is a substantially larger, deeper and colder lake and historically has not experienced substantial changes in trophic state that could be an indication that the depth of Thaumarchaeota production may have been different in the past. Therefore, it is likely that $\mathrm{TEX}_{86}$ values in the past also reflected a similar combination of overturning and hypolimnetic water temperatures as observed at present day. These temperatures likely relate to the atmospheric temperature in a more indirect way relative to the epilimnetic water temperatures, as most of the warmth collected in the water of epilimnion during the stratified period is lost to the atmosphere and only small fraction of this energy is ultimately mixed into the deeper waters. Water temperatures throughout the water column of Lake Superior will be affected by a significant increase or decrease of atmospheric temperature 
surrounding the lake. However, mixed and hypolimnetic water temperatures are expected to change at a slower pace and with smaller amplitude than changes in atmospheric temperature, and observed changes on these water temperatures could be within the error of the $\mathrm{TEX}_{86}$ calibration. Considering the current limited information of the ecology of lacustrine Thaumarchaeota it would be speculative to theorize on how changes of water temperatures and thermal stratification of the water column of Lake Superior would change the depth of Thaumarchaeota production in the water column. In this study Thaumarchaeota were never observed in substantial abundance at depths above the thermocline. A deepening of the thermocline as a result of increasing atmospheric temperatures may therefore result in that Thaumarchaeota may reside deeper in the water column. While a cooling of Lake Superior may result in a shallower thermocline compared to present, which could move the niche of Thaumarchaeota closer to the surface, although likely still below depths of thermocline.

The current lacustrine calibration of the proxy by Powers et al. (2010) assumed that the GDGT signal that was incorporated into the sediment predominantly originated form surface waters. Recent results from Lake Lucerne (Blaga et al., 2011) and Lake Superior (this study), but also from marine systems (e.g. Lopes Huguet et al., 2007c; dos Santos et al., 2010) show that thaumarchaeotal GDGT lipids that are produced around or below the thermocline (i.e. slightly deeper in the water column) can dominate the signal that is transported to the sediment. Other studies observed through empirical correlations of GDGT lipid abundances and $\mathrm{TEX}_{86}$ values suspended in the water column and in sediments that the GDGT signal in Lake Lugano and Brienz originated from the surface waters (Bechtel et al., 2010). The observed differences in the location of Thaumarchaeota export production in the water column among lakes signify differences among lacustrine systems, which may partially explain some of the observed scatter in the lacustrine $\mathrm{TEX}_{86}$ calibration. Currently there is limited information available about the vertical niche of Thaumarchaeota and origin of the $\mathrm{TEX}_{86}$ signal in the sediments for the other lakes that were incorporated in the Powers et al. (2010) lacustrine $\mathrm{TEX}_{86}$ calibration, and therefore it is speculative to hypothesize if or in what other lakes the $\mathrm{TEX}_{86}$ in the sediment may also reflect sub-thermocline water temperatures. A sediment trap study in Lake Baikal argued to be mainly reflecting surface temperatures with a certain bias to observed surface temperatures in autumn as $\mathrm{TEX}_{86}$ inferred temperatures using an early lacustrine calibration of Powers et al. (2005) were warmer than the observed water temperatures at depths below the thermocline (Escala Pascual, 2009). However, applying the new Powers et al. (2010) calibration to the data from this study would shift inferred temperatures downwards towards the range of average water temperatures observed below the thermocline in Lake Baikal and therefore cannot exclude that the $\mathrm{TEX}_{86}$ may reflect a sub-thermocline temperature in this lake. In the future it might be necessary to revisit the lacustrine $\mathrm{TEX}_{86}$ calibration as more information about the ecology of Thaumarchaeota come available that provides a better understanding of both the seasonality and variability in the vertical nice of Thaumarchaeota in lacustrine systems. This will likely yield a more robust calibration that allows for accurate interpretations of records of past temperature variability using the $\mathrm{TEX}_{86}$ temperature proxy in lacustrine sediment archives.

\subsection{The vertical distribution of branched core GDGTs}

Branched GDGTs are thought to be produced primarily by soil bacteria, possibly Acidobacteria (Sinninghe Damsté et al., 2011), and until recently the presence of branched GDGTs in aquatic systems was therefore interpreted as solely coming from soil erosion by terrestrial runoff (Hopmans et al., 2004; Huguet et al., 2007b; Walsh et al., 2008; Verschuren et al., 2009; Smith et al., 2012). Recent studies, however, suggest that branched GDGTs may also be produced within lacustrine water columns or sediments or within marine sediments (Peterse et al., 2009; Sinninghe Damsté et al., 2009; Tierney and Russell, 2009; Blaga et al., 2009; Tierney et al., 2010). Fluxes of branched GDGTs and BIT values in settling particles collected by sediment traps are discussed above as mainly reflecting resuspended and laterally transported particles towards the sample site. Branched GDGT concentrations in SPM were generally quite low, but in the hypolimnion concentrations increased significantly with depth to maximum abundances close to the lake bottom. During the stratified period, branched GDGT concentrations were very low $(\sim 3 \mathrm{pg} / \mathrm{L})$ in the epilimnion, but increase 1-2 orders of magnitude in the hypolimnion (Fig. 3). Generally, this pattern is similar to that previously documented in Lake Challa, in which branched GDGTs are thought to be delivered to the lake by terrestrial runoff as the highest flux of branched GDGTs occurs just after the short rainy season (Sinninghe Damsté et al., 2009). However, it was noted that the distribution of branched GDGTs in Lake Challa SPM suggests an additional source of branched GDGTs, possibly in situ production in the lake sediments or water column or groundwater transport (Sinninghe Damsté et al., 2009). The vertical pattern of the branched GDGT abundance in Lake Superior resembles that of isoprenoid GDGTs; however, there are some marked differences. In the surface waters the branched GDGTs are relatively more abundant compared to crenarchaeol during the periods of thermal stratification resulting in higher BIT values observed in the top water layers (Fig. 3). This may be explained by the extremely low crenarchaeol concentrations observed at those depths. Additionally, the increase in branched GDGTs at greater depths appears to be slightly stronger compared to isoprenoid GDGTs as can be seen by a higher BIT index at greater depths (Fig. 3). The generally ubiquitous distribution of branched GDGTs during the unstratified period in Lake Superior can be explained by mixing of the water column during overturning conditions. The vertical distribution of branched GDGTs during the stratified period may be an indication of in situ production of branched GDGTs at the sediment water interface or slightly deeper in the sediments, or even potentially in the oxic water column, 
although this would contradict the hypothesis that they are synthesized by anaerobic bacteria (Weijers et al., 2006a,b). Since we only studied branched GDGT lipids we cannot further constrain their potential sources; analysis of intact polar branched GDGTs would be required (cf. Liu et al., 2010; Peterse et al., 2011).

\section{CONCLUSIONS}

We investigated the vertical and temporal distribution of Thaumarchaeota derived core isoprenoid GDGT lipids in Lake Superior through sampling and analysis of suspended particulate matter profiles from the water column combined with a 3 year long sampling of settling particles in sediment traps at an open lake location in Lake Superior. The results from this study indicate that Thaumarchaeota are present throughout the water column during times of overturning, but mainly reside below the thermocline $(\sim 40 \mathrm{~m})$ during periods of thermal stratification. Fluxes of thaumarchaeotal produced GDGTs mainly occurred during winter and late spring/early summer and start when the lake is isothermal. A strong covariance among the total mass accumulation flux and isoprenoid and branched GDGT fluxes was observed, where maximum fluxes are associated with elevated BIT index values. This suggests that the elevated fluxes may be related to an influx of previously deposited, resuspended and laterally transported particles from shallower near shore regions of Lake Superior and therefore clouds the interpretation of the observed fluxes in terms of the seasonality of the Thaumarchaeota production in Lake Superior.

TEX $_{86}$ values in SPM were in good agreement with the in situ water temperatures during all sampling periods. $\mathrm{TEX}_{86}$ values from three years of settling particles showed a small range of observed temperatures and revealed that the sedimentary $\mathrm{TEX}_{86}$ signal during the thermally stratified period likely originated from depths below the thermocline. The $\mathrm{TEX}_{86}$ in settling particles during the winter period of maximum flux did not capture the cold water temperatures that are observed throughout the water column during this period, which supports our hypothesis that these fluxes were caused by sediment focusing. Flux weighted $\mathrm{TEX}_{86}$ temperatures from the sediment traps agree well with $\mathrm{TEX}_{86}$ temperature from surface sediments from the same location and, within the error of the calibration, are close to the averaged water temperatures observed at subsurface at $\sim 40 \mathrm{~m}$ water depth.

Based on the observed vertical distribution of Thaumarchaeota in the water column of Lake Superior, the measured $\mathrm{TEX}_{86}$ values in surface sediments appear to reflect a combination of mixed and sub-thermocline (below $40 \mathrm{~m}$ depth) water temperatures. This is effectively the same as the annual average water temperature observed at depths below $40 \mathrm{~m}$ in Lake Superior. These deeper water temperatures can change as a result of changes in the atmospheric temperatures, but due to the high thermal mass of the hypolimnion in Lake Superior and the fact that water at those depths is physically separated from the epilimnion and atmosphere during the stratified period, the overall amplitude of temperature change is expected to be smaller than the observed atmospheric temperature change surrounding the lake. Thus, trends in $\mathrm{TEX}_{86}$ inferred temperatures in sediment records of Lake Superior, and similar lakes, are likely to reflect subsurface temperature variability rather than that of surface temperatures.

\section{ACKNOWLEDGEMENTS}

Two anonymous reviewers are acknowledged for providing helpful comments that have improved the earlier version of our manuscript. We would like to thank the captain and crew of the R/V Blue Heron. We also thank Sarah Grosshuesch Brent Dalzell, Clarissa Booth, Ben Marsh, Jenna Bergin, Matt Stuart, Brittany Kruger, Melissa Berke, Liz Minor, Brandon Stephens and Jeff Strom for sampling assistance, and Ellen Hopmans and Jort Ossebaar for analytical support. This work was supported by NSF Grant \#OCE-0452927 to J.P.W. and R.H. J.P.W. acknowledges support from the Gledden Fellowship. J.S.S.D. and S.S. received funding from the ERC project Pacemaker. This work forms contribution 2401-JW at the Centre for Water Research, The University of Western Australia.

\section{REFERENCES}

Adrian R., O'Reilly C. M., Zagarese H., Baines S. B., Hessen D. O., Keller W., Livingstone D. M., Sommaruga R., Straile D., Van Donk E., Weyhenmeyer G. A. and Winder M. (2009) Lakes as sentinels of climate change. Limnol. Oceanogr. 54, 2283-2297.

Austin J. A. and Colman S. M. (2007) Lake Superior summer water temperatures are increasing more rapidly than regional air temperatures: a positive ice-albedo feedback. Geophys. Res. Lett. 34, 5.

Baker J. E. and Eisenreich S. J. (1989) PCBs and PAHs as tracers of particulate dynamics in large lakes. J. Gr. Lakes Res. 15, 84103.

Baker J. E., Eisenreich S. J. and Eadie B. J. (1991) Sediment trap fluxes and benthic recycling of organic-carbon, polycyclic aromatic-hydrocarbons, and polychlorobiphenyl congeners in Lake-Superior. Environ. Sci. Technol. 25, 500-509.

Bechtel A., Smittenberg R. H., Bernasconi S. M. and Schubert C. J. (2010) Distribution of branched and isoprenoid tetraether lipids in an oligotrophic and a eutrophic Swiss lake: insights into sources and GDGT-based proxies. Org. Geochem. 41, 822-832.

Blaga C. I., Reichart G. J., Heiri O. and Sinninghe Damsté J. S. (2009) Tetraether membrane lipid distributions in watercolumn particulate matter and sediments: a study of 47 European lakes along a north-south transect. J. Paleolimnol. 41, 523-540.

Blaga C. I., Reichart G. J., Vissers E. W., Lotter A. F., Anselmetti F. S. and Sinninghe Damsté J. S. (2011) Seasonal changes in glycerol dialkyl glycerol tetraether concentrations and fluxes in a perialpine lake: Implications for the use of the $\mathrm{TEX}_{86}$ and BIT proxies. Geochim. Cosmochim. Acta 75, 6416-6428.

Brochier-Armanet C., Boussau B., Gribaldo S. and Forterre P. (2008) Mesophilic crenarchaeota: proposal for a third archaeal phylum, the Thaumarchaeota. Nat. Rev. Microbiol. 6, 245-252.

Cohen A. S. (2003) Paleolimnology: The History and Evolution of Lake Systems. Oxford University Press.

Cotner J. B., Biddanda B. A., Makino M. and Stets E. (2004) Organic carbon biogeochemistry of Lake Superior. Aquat. Ecosyst. Health Manage. 7, 451-464.

de la Torre J. R., Walker C. B., Ingalls A. E., Konneke M. and Stahl D. A. (2008) Cultivation of a thermophilic ammonia 
oxidizing archaeon synthesizing crenarchaeol. Environ. Microbiol. 10, 810-818.

dos Santos R. A. L., Prange M., Castaneda I. S., Schefuss E., Mulitza S., Schulz M., Niedermeyer E. M., Sinninghe Damsté J. S. and Schouten S. (2010) Glacial-interglacial variability in Atlantic meridional overturning circulation and thermocline adjustments in the tropical North Atlantic. Earth Planet. Sci. Lett. 300, 407-414.

Eadie B. J., Chambers R. L., Gardner W. S. and Bell G. L. (1984) Sediment trap studies in Lake-Michigan-resuspension and chemical fluxes in the southern basin. J. Gr. Lakes Res. 10, 307-321.

Efron B. (1983) Estimating the error rate of a prediction ruleimprovement on cross-validation. J. Am. Stat. Assoc. 78, 316331.

Escala Pascual M. (2009) Application of Tetraether Membrane Lipids as Proxies for Continental Climate Reconstruction in Iberian and Siberian Lakes. Universitat Autònoma de Barcelona.

Flood R. D. (1989) Submersible studies of current-modified bottom topography in lake-superior. J. Gr. Lakes Res. 15, 3-14.

Fuhrman J. A., Comeau D. E., Hagstrom A. and Chan A. M. (1988) Extraction from natural planktonic microorganisms of DNA suitable for molecular biological studies. Appl. Environ. Microbiol. 54, 1426-1429.

Gerten D. and Adrian R. (2001) Differences in the persistency of the North Atlantic oscillation signal among lakes. Limnol. Oceanogr. 46, 448-455.

Gliozzi A., Paoli G., Derosa M. and Gambacorta A. (1983) Effect of isoprenoid cyclization on the transition-temperature of lipids in thermophilic archaebacteria. Biochim. Biophys. Acta 735, 234-242.

Guildford S. J., Bootsma H. A., Fee E. J., Hecky R. E. and Patterson G. (2000) Phytoplankton nutrient status and mean water column irradiance in Lakes Malawi and Superior. Ecosyst. Health Manage., 35-45.

Harvey H. R., Fallon R. D. and Patton J. S. (1986) The effect of organic-matter and oxygen on the degradation of bacterialmembrane lipids in marine-sediments. Geochim. Cosmochim. Acta 50, 795-804.

Hawley N. (2000) Sediment resuspension near the Keweenaw Peninsula, Lake Superior during the fall and winter 1990-1991. J. Gt. Lakes Res. 26, 495-505.

Herfort L., Schouten S., Abbas B., Veldhuis M. J. W., Coolen M. J. L., Wuchter C., Boon J. P., Herndl G. J. and Sinninghe Damsté J. S. (2007) Variations in spatial and temporal distribution of Archaea in the North Sea in relation to environmental variables. FEMS Microbiol. Ecol. 62, 242-257.

Hopmans E. C., Weijers J. W. H., Schefuss E., Herfort L., Sinninghe Damsté J. S. and Schouten S. (2004) A novel proxy for terrestrial organic matter in sediments based on branched and isoprenoid tetraether lipids. Earth Planet. Sci. Lett. 224, $107-116$.

Huguet C., Hopmans E. C., Febo-Ayala W., Thompson D. H., Sinninghe Damsté J. S. and Schouten S. (2007a) An improved method to determine the absolute abundance of glycerol dibiphytanyl glycerol tetraether lipids (vol. 37, pg. 1036, 2006). Org. Geochem. 38, 1457.

Huguet C., Schimmelmann A., Thunell R., Lourens L. J., Sinninghe Damsté J. S. and Schouten S. (2007b) A study of the TEX86 paleothermometer in the water column and sediments of the Santa Barbara Basin, California. Paleoceanography 22, 9.

Huguet C., Smittenberg R. H., Boer W., Damste J. S. S. and Schouten S. (2007c) Twentieth century proxy records of temperature and soil organic matter input in the Drammensfjord, southern Norway. Org. Geochem. 38, 1838-1849.

Huguet C., Martens-Habbena W., Urakawa H., Stahl D. A. and Ingalls A. E. (2010) Comparison of extraction methods for quantitative analysis of core and intact polar glycerol dialkyl glycerol tetraethers (GDGTs) in environmental samples. Limnol. Oceanogr. Methods 8, 127-145.

Keough B. P., Schmidt T. M. and Hicks R. E. (2003) Archaeal nucleic acids in picoplankton from great lakes on three continents. Microb. Ecol. 46, 238-248.

Kim J. H., Schouten S., Hopmans E. C., Donner B. and Sinninghe Damsté J. S. (2008) Global sediment core-top calibration of the TEX86 paleothermometer in the ocean. Geochim. Cosmochim. Acta 72, 1154-1173.

Kim J. H., van der Meer J., Schouten S., Helmke P., Willmott V., Sangiorgi F., Koc N., Hopmans E. C. and Sinninghe Damsté J. S. (2010) New indices and calibrations derived from the distribution of crenarchaeal isoprenoid tetraether lipids: implications for past sea surface temperature reconstructions. Geochim. Cosmochim. Acta 74, 4639-4654.

Kish J. L. (2010) Panktonic Archaeal Communities Change Seasonally in Lake Superior. University of Minnesota Duluth.

Konneke M., Bernhard A. E., de la Torre J. R., Walker C. B., Waterbury J. B. and Stahl D. A. (2005) Isolation of an autotrophic ammonia-oxidizing marine archaeon. Nature 437, 543-546.

Lipp J. S., Morono Y., Inagaki F. and Hinrichs K. U. (2008) Significant contribution of Archaea to extant biomass in marine subsurface sediments. Nature 454, 991-994.

Liu X. L., Leider A., Gillespie A., Groger J., Versteegh G. J. M. and Hinrichs K. U. (2010) Identification of polar lipid precursors of the ubiquitous branched GDGT orphan lipids in a peat bog in Northern Germany. Org. Geochem. 41, 653660.

Livingstone D. M. (2003) Impact of secular climate change on the thermal structure of a large temperate central European lake. Clim. Change 57, 205-225.

Livingstone D. M. and Lotter A. F. (1998) The relationship between air and water temperatures in lakes of the Swiss Plateau: a case study with palaeolimnological implications. $J$. Paleolimnol. 19, 181-198.

Lliros M., Gich F., Plasencia A., Auguet J. C., Darchambeau F., Casamayor E. O., Descy J. P. and Borrego C. (2010) Vertical distribution of ammonia-oxidizing crenarchaeota and methanogens in the epipelagic waters of Lake Kivu (RwandaDemocratic Republic of the Congo). Appl. Environ. Microbiol. 76, 6853-6863.

MacGregor B. J., Moser D. P., Alm E. W., Nealson K. H. and Stahl D. A. (1997) Crenarchaeota in Lake Michigan sediment. Appl. Environ. Microbiol. 63, 1178-1181.

Meyers P. A. (1997) Organic geochemical proxies of paleoceanographic, paleolimnologic, and paleoclimatic processes. Org. Geochem. 27, 213-250.

Pascoe D. A. and Hicks R. E. (2004) Genetic structure and community DNA similarity of picoplankton communities from the Laurentian Great Lakes. J. Gt. Lakes Res. 30, 185-195.

Pernthaler J., Glockner F. O., Unterholzner S., Alfreider A., Psenner R. and Amann R. (1998) Seasonal community and population dynamics of pelagic bacteria and archaea in a high mountain lake. Appl. Environ. Microbiol. 64, 4299-4306.

Peterse F., Kim J. H., Schouten S., Kristensen D. K., Koc N. and Sinninghe Damsté J. S. (2009) Constraints on the application of the MBT/CBT palaeothermometer at high latitude environments (Svalbard, Norway). Org. Geochem. 40, 692-699.

Peterse F., Hopmans E. C., Schouten S., Mets A., Rijpstra W. I. C. and Sinninghe Damsté J. S. (2011) Identification and distribu- 
tion of intact branched tetraether lipids in peat and soils. Org. Geochem. 42, 1007-1015.

Pitcher A., Rychlik N., Hopmans E. C., Spieck E., Rijpstra W. I. C., Ossebaar J., Schouten S., Wagner M. and Sinninghe Damsté J. S. (2010) Crenarchaeol dominates the membrane lipids of Candidatus Nitrososphaera gargensis, a thermophilic Group I. 1b Archaeon. ISME J. 4, 542-552.

Pitcher A., Hopmans E. C., Mosier A. C., Park S.-J., Rhee S.-K., Francis C. A., Schouten S. and Sinninghe Damsté J. S. (2011) Core and intact polar glycerol dibiphytanyl glycerol tetraether lipids of ammonia-oxidizing archaea enriched from marine and estuarine sediments. Appl. Environ. Microbiol. (AEM.02758$10)$.

Powers L. A., Werne J. P., Johnson T. C., Hopmans E. C., Sinninghe Damsté J. S. and Schouten S. (2004) Crenarchaeotal membrane lipids in lake sediments: a new paleotemperature proxy for continental paleoclimate reconstruction? Geology 32, 613-616.

Powers L. A., Johnson T. C., Werne J. P., Castanada I. S., Hopmans E. C., Sinninghe Damsté J. S. and Schouten S. (2005) Large temperature variability in the southern African tropics since the Last Glacial Maximum. Geophys. Res. Lett. 32, 4 .

Powers L., Werne J. P., Vanderwoude A. J., Sinninghe Damsté J. S., Hopmans E. C. and Schouten S. (2010) Applicability and calibration of the TEX86 paleothermometer in lakes. Org. Geochem. 41, 404-413.

Quinn F. H. (1992) Hydraulic residence times for the Laurentian Great-Lakes. J. Gt. Lakes Res. 18, 22-28.

Robertson D. M. and Ragotzkie R. A. (1990) Changes in the thermal structure of moderate to large sized lakes in response to changes in air-temperature. Aquat. Sci. 52, 360-380.

Schleper C., Holben W. and Klenk H. P. (1997) Recovery of Crenarchaeotal ribosomal DNA sequences from freshwaterlake sediments. Appl. Environ. Microbiol. 63, 321-323.

Schouten S., Hopmans E. C., Pancost R. D. and Sinninghe Damsté J. S. (2000) Widespread occurrence of structurally diverse tetraether membrane lipids: evidence for the ubiquitous presence of low-temperature relatives of hyperthermophiles. Proc. Natl. Acad Sci. 97, 14421-14426.

Schouten S., Hopmans E. C., Schefuss E. and Sinninghe Damsté J. S. (2002) Distributional variations in marine crenarchaeotal membrane lipids: a new tool for reconstructing ancient sea water temperatures? Earth Planet. Sci. Lett. 204, 265-274.

Schouten S., Huguet C., Hopmans E. C., Kienhuis M. V. M. and Sinninghe Damsté J. S. (2007) Analytical methodology for TEX86 paleothermometry by high-performance liquid chromatography/atmospheric pressure chemical ionization-mass spectrometry. Anal. Chem. 79, 2940-2944.

Schouten S., Hopmans E. C., Baas M., Boumann H., Standfest S., Konneke M., Stahl D. A. and Sinninghe Damsté J. S. (2008) Intact membrane lipids of "Candidatus Nitrosopumilus maritimus", a cultivated representative of the cosmopolitan mesophilic group I crenarchaeota. Appl. Environ. Microbiol. 74, 2433-2440.

Seegers B. (2009) Lake Superior Zooplankton Community Grazing and its Implications for the Deep Chlorophyll Maximum. University of Minnesota.

Shevenell A. E., Ingalls A. E., Domack E. W. and Kelly C. (2011) Holocene Southern Ocean surface temperature variability west of the Antarctic Peninsula. Nature 470, 250-254.

Sinninghe Damsté J. S., Schouten S., Hopmans E. C., van Duin A. C. T. and Geenevasen J. A. J. (2002) Crenarchaeol: the characteristic core glycerol dibiphytanyl glycerol tetraether membrane lipid of cosmopolitan pelagic crenarchaeota. $J$. Lipid Res. 43, 1641-1651.
Sinninghe Damsté J. S., Ossebaar J., Abbas B., Schouten S. and Verschuren D. (2009) Fluxes and distribution of tetraether lipids in an equatorial African lake: constraints on the application of the TEX86 palaeothermometer and BIT index in lacustrine settings. Geochim. Cosmochim. Acta 73, 42324249.

Sinninghe Damsté J. S., Rijpstra W. I. C., Hopmans E. C., Weijers J. W. H., Foesel B. U., Overmann J. and Dedysh S. N. (2011) 13,16-Dimethyl octacosanedioic acid (iso-diabolic acid): a common membrane-spanning lipid of Acidobacteria subdivisions 1 and 3. Appl. Environ. Microbiol. 77, 4147-4154.

Smith R. W., Bianchi T. S. and Li X. (2012) A re-evaluation of the use of branched GDGTs as terrestrial biomakers: implications for the BIT Index. Geochim. Cosmochim. Acta 80, 12-29.

Spang A., Hatzenpichler R., Brochier-Armanet C., Rattei T., Tischler P., Spieck E., Streit W., Stahl D. A., Wagner M. and Schleper C. (2010) Distinct gene set in two different lineages of ammonia-oxidizing archaea supports the phylum Thaumarchaeota. Trends Microbiol. 18, 331-340.

Straile D., Johnk K. and Rossknecht H. (2003) Complex effects of winter warming on the physicochemical characteristics of a deep lake. Limnol. Oceanogr. 48, 1432-1438.

Tierney J. E. and Russell J. M. (2009) Distributions of branched GDGTs in a tropical lake system: implications for lacustrine application of the MBT/CBT paleoproxy. Org. Geochem. 40, 1032-1036.

Tierney J. E., Russell J. M., Huang Y. S., Sinninghe Damsté J. S., Hopmans E. C. and Cohen A. S. (2008) Northern hemisphere controls on tropical southeast African climate during the past 60,000 years. Science 322, 252-255.

Tierney J. E., Russell J. M., Eggermont H., Hopmans E. C., Verschuren D. and Sinninghe Damsté J. S. (2010) Environmental controls on branched tetraether lipid distributions in tropical East African lake sediments. Geochim. Cosmochim. Acta 74, 4902-4918.

Urban N. R., Auer M. T., Green S. A., Lu X., Apul D. S., Powell K. D. and Bub L. (2005) Carbon cycling in Lake Superior. $J$. Geophys. Res. [Oceans] 110, 17.

Verschuren D., Sinninghe Damste J. S., Moernaut J., Kristen I., Blaauw M., Fagot M. and Haug G. H. (2009) Half-precessional dynamics of monsoon rainfall near the East African Equator. Nature 462 637-641.

Walsh E. M., Ingalls A. E. and Keil R. G. (2008) Sources and transport of terrestrial organic matter in Vancouver Island fjords and the Vancouver-Washington Margin: a multiproxy approach using delta $\mathrm{C}-13$ (org), lignin phenols, and the ether lipid BIT index. Limnol. Oceanogr. 53, 1054-1063.

Weijers J. W. H., Schouten S., Hopmans E. C., Geenevasen J. A. J., David O. R. P., Coleman J. M., Pancost R. D. and Sinninghe Damsté J. S. (2006a) Membrane lipids of mesophilic anaerobic bacteria thriving in peats have typical archaeal traits. Environ. Microbiol. 8, 648-657.

Weijers J. W. H., Schouten S., Spaargaren O. C. and Sinninghe Damsté J. S. (2006b) Occurrence and distribution of tetraether membrane lipids in soils: implications for the use of the TEX86 proxy and the BIT index. Org. Geochem. 37, 1680-1693.

White D. C., Davis W. M., Nickels J. S., King J. D. and Bobbie R. J. (1979) Determination of the sedimentary microbial biomass by extractable lipid phosphate. Oecologia 40, 51-62.

Woltering M., Johnson T. C., Werne J. P., Schouten S. and Sinninghe Damsté J. S. (2011) Late Pleistocene temperature history of Southeast Africa: a TEX86 temperature record from Lake Malawi. Palaeogeogr. Palaeoclimatolo. Palaeoecol. 303, 93-102.

Wuchter C., Schouten S., Coolen M. J. L. and Sinninghe Damsté J. S. (2004) Temperature-dependent variation in the distribution 
of tetraether membrane lipids of marine Crenarchaeota: implications for TEX86 paleothermometry. Paleoceanography 19, 10.

Wuchter C., Abbas B., Coolen M. J. L., Herfort L., van Bleijswijk J., Timmers P., Strous M., Teira E., Herndl G. J., Middelburg J. J., Schouten S. and Sinninghe Damsté J. S. (2006) Archaeal nitrification in the ocean. Proc. Natl Acad. Sci. USA 103, $12317-12322$.
Zigah P. K., Minor E. C., Werne J. P. and Leigh McCallister S. (2011) Radiocarbon and stable carbon isotopic insights into provenance and cycling of carbon in Lake Superior. Limnol. Oceanogr. 56, 867-886.

Associate editor: Thomas S. Bianchi 